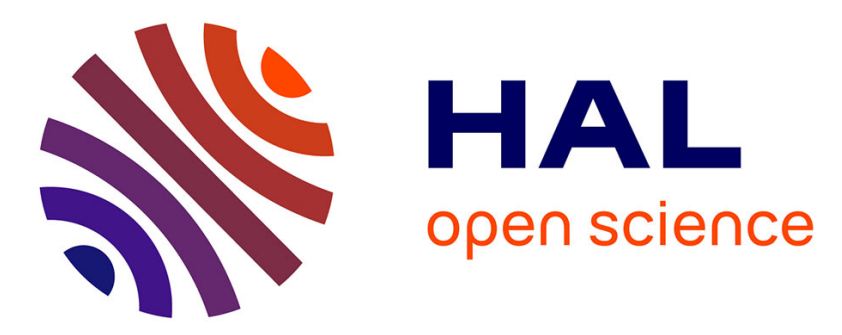

\title{
Surface precipitation electric current produced by convective rains during the Mesoscale Alpine Program.
}

S. Soula, S. Chauzy, M. Chong, S. Coquillat, J.-F. Georgis, Y. Seity, P. Tabary

\section{To cite this version:}

S. Soula, S. Chauzy, M. Chong, S. Coquillat, J.-F. Georgis, et al.. Surface precipitation electric current produced by convective rains during the Mesoscale Alpine Program.. Journal of Geophysical Research, 2003, 108, (D13), pp.4395. 10.1029/2001JD001588 . hal-00136470

\section{HAL Id: hal-00136470 \\ https://hal.science/hal-00136470}

Submitted on 8 Sep 2020

HAL is a multi-disciplinary open access archive for the deposit and dissemination of scientific research documents, whether they are published or not. The documents may come from teaching and research institutions in France or abroad, or from public or private research centers.
L'archive ouverte pluridisciplinaire HAL, est destinée au dépôt et à la diffusion de documents scientifiques de niveau recherche, publiés ou non, émanant des établissements d'enseignement et de recherche français ou étrangers, des laboratoires publics ou privés. 


\title{
Surface precipitation electric current produced by convective rains during the Mesoscale Alpine Program
}

\author{
S. Soula, S. Chauzy, M. Chong, S. Coquillat, J. F. Georgis, and Y. Seity \\ Laboratoire d'Aérologie, Observatoire Midi-Pyrénées, UMR 5560, Université Paul Sabatier-Centre National de la Recherche \\ Scientifique, Toulouse, France \\ P. Tabary ${ }^{1}$ \\ Centre d'Étude des Environnements Terrestre et Planétaires, Vélizy, France
}

Received 10 December 2001; revised 19 July 2002; accepted 27 December 2002; published 12 July 2003.

[1] This paper presents data from measurements of electric field, precipitation current density, and rainfall parameters performed during the Mesoscale Alpine Program experiment in northern Italy during autumn 1999. Several days of the period provided substantially charged rainfall of both polarities. The average proportions of each polarity are close, but the negative one is slightly larger (54\%). Three Doppler radars provided a description of the cells' development and dynamics. A case of a deeply convective cell occurred on 17 September 1999. In this case, the precipitation current density is first positive, reaches more than $100 \mathrm{nA} \mathrm{m}^{-2}$, and changes its polarity when the rainfall is maximum with a value close to $200 \mathrm{~mm} \mathrm{~h}^{-1}$. We also consider several shallow convective cells passing over the experimental site on 3 October. Two cells among a set of eight did not produce electrical parameter variations although they displayed development and radar reflectivity structure similar to that of the others. The dynamical study shows that the vertical velocity (averaged over $1 \mathrm{~km} \times 1 \mathrm{~km}$ mesh) was weaker within these two cells with a value of only $0.5 \mathrm{~m} \mathrm{~s}^{-1}$ while it reached $1.5 \mathrm{~m} \mathrm{~s}^{-1}$ within the other cells. Both charge polarities were observed on the rain produced by electrified cells, first the negative one and then the positive one. A very tight correlation between surface electric field and precipitation current is observed out at the surface, displaying the mirror image effect. The ground electric field is due to the cloud charge, in contrast with that carried down to the ground by the rainfall. In order to reproduce the field evolution created by the cell passage, we test different models of charge distribution. A model including a horizontal distribution is found to provide a field evolution in best agreement with the observations. According to this model the net charge of the cloud above the site is chronologically positive and negative, which can be the result of the evacuation of an opposite charge by the rain. INDEX TERMS: 3304 Meteorology and Atmospheric Dynamics: Atmospheric electricity; 3314 Meteorology and Atmospheric Dynamics: Convective processes; 3324 Meteorology and Atmospheric Dynamics: Lightning; 3354 Meteorology and Atmospheric Dynamics: Precipitation (1854); KEYWORDS: convective cell, precipitation current, electric field, raindrop charge, mirror image effect

Citation: Soula, S., S. Chauzy, M. Chong, S. Coquillat, J. F. Georgis, Y. Seity, and P. Tabary, Surface precipitation electric current produced by convective rains during the Mesoscale Alpine Program, J. Geophys. Res., 108(D13), 4395, doi:10.1029/2001JD001588, 2003.

\section{Introduction}

[2] The first measurements of precipitation current were performed by Simpson [1949], simultaneously with those of potential gradient below disturbed weather conditions. He noted similar trends with opposite polarities for both parameters, what is called the mirror image effect. He interpreted

\footnotetext{
${ }^{1}$ Now at Météo-France, Trappes, France.
}

the presence of charge on falling raindrops by the corona ions capture [Wilson, 1929] above ground. Later, this effect was also observed by Ramsay and Chalmers [1960]. They sometimes noted a lag time between both variations of precipitation current and electric field. This latter observation led to conclude that the field evolution could be influenced by the approach of the charged rain. These considerations were revisited by Moore and Vonnegut [1977] to interpret the field excursion associated with precipitation (FEAWP) observed below thunderstorm.

[3] For this surface precipitation current both polarities occur and the values of its density usually reach some 


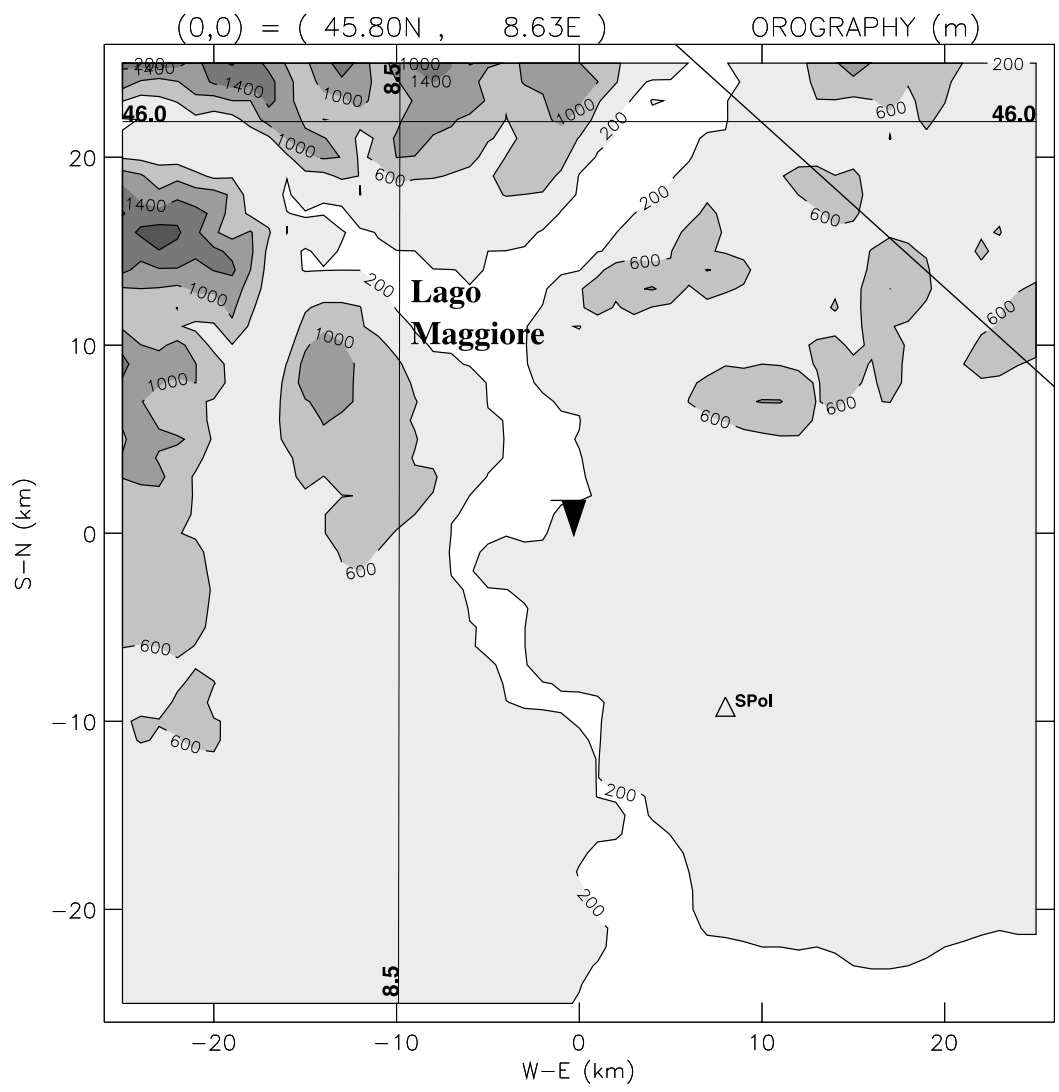

Figure 1. Topographic map (contours every $400 \mathrm{~m}$ starting at $200 \mathrm{~m}$ ) within the domain of groundbased dual-Doppler radar analysis. Only the location of the S-Pol radar (open triangle) is included in this domain. The site of Ispra is in the center $(0,0)$ marked with a black solid triangle.

$\mathrm{nA} \mathrm{m}^{-2}$, as indicated by Rust and Moore [1974] or Soula and Chauzy [1997]. Within or below the cloud this density is generally higher [Marshall and Winn, 1982]. The Wilson [1929] capture could be responsible for the differences observed between altitude and ground. However, other interpretations were given to justify the predominance of the positive polarity in the rain charge. So, the positive charge center located in the lower part of the thundercloud could provide the positive charge carried at the surface by the rain [Holden et al., 1980; Marshall and Winn, 1982]. In this case, several interpretations are put forward for the origin of this positive charge, either due to the noninductive processes at low altitude where the temperature is larger than $-10^{\circ} \mathrm{C}$ [Takahashi, 1978] or deposited by the lightning flash at the base of the cloud [Marshall and Winn, 1982]. This mechanism also leads to interpret the surface field reverse as the result of the approach of the positively charged rain.

[4] From ground measurements of individual charge on raindrops made by Chauzy and Despiau [1980] and from other measurements, Soula and Chauzy [1997] presented a budget with a predominance of negative charge transferred to the ground. They proposed a new interpretation for the electric field/precipitation current relation where the rain charge corresponds to that creating the electric field before the shower. So, the field reverse was the result of the arrival of the rain at the ground and not of its approach. The mirror image effect was then observed after this reverse. In fact, the precipitation charge started with negative charge and then could reverse its polarity. However, these observations did not permit to validate the Wilson capture theory by raindrops to explain the charge polarity of the raindrops.

[5] In autumn 1999, the special observing period of the Mesoscale Alpine Program (MAP) (7 September to 15 November 1999) took place over the Alps area. One of the main objectives was to investigate the mechanism of orographically induced heavy precipitation events with special emphasis on their dynamics, microphysics and hydrological consequences [Bougeault et al., 2001]. Most of the time, the rainy events observed during the Intensive Observation Periods (IOPs) were accompanied with electrical phenomena and presented convective characteristics as observed by ground-based Doppler radars. Consequently this experiment provides an opportunity to study the characteristics of the precipitation current produced by convective rains and its eventual correlation with other characteristics of the cloud. In this study, the electrical data collected during IOP 2A (17 September 1999) and IOP 5 (3 October 1999) are analyzed concurrently with the Doppler-derived wind fields.

\section{Measurement Conditions}

[6] The measuring system used for the study of the precipitation current included three ground-based sensors: an electric field mill, a new specific sensor for the precipitation current and a disdrometer for the raindrop spectrum and rate. The experimental site was located in northern Italy, by the Lago Maggiore, at the Joint European Research 


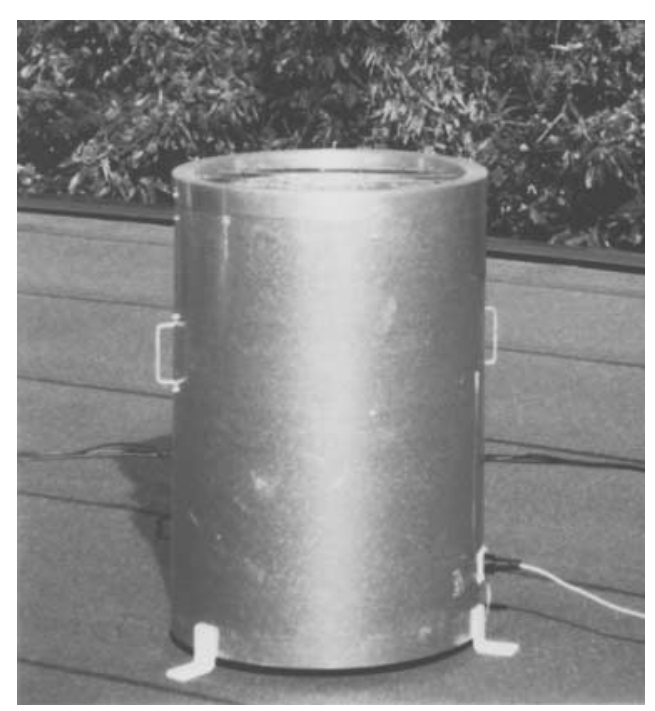

Figure 2. Sensor of precipitation current.

Center in Ispra (Figure 1). It corresponds to the center $(0,0)$ of this $50 \times 50 \mathrm{~km}^{2}$ map displaying the relief and the y-shaped Lago Maggiore. This map can help understanding the flow patterns at low altitudes discussed in the following and retrieved from Doppler radar observations. The sensors were installed on the flat roof of a building; thus the value of the detected electric field was probably enhanced by the building. Anyway, we essentially take into account the variation of the electric field in this study. In order to consider the horizontal extent of the electrical parameters, a second couple of sensors (field mill and precipitation current sensor) was installed in a flat field covered with grass and at a distance of 600 meters in the direction of the dominant wind, but too far to be used for the first field mill calibration. Both measurement sites are referred to as site 1 and site 2 , respectively.

[7] The measurement head of the electric field mill was downward to avoid the rain disturbances. The time resolution of $5 \mathrm{~ms}$ permitted to describe the electric field evolution between lightning flashes and to appreciate the discontinuities produced by the lightning flashes. It was crosscalibrated with another field mill located flush with the ground. The precipitation current measurement was performed by a new sensor developed at the laboratory, according to the principle proposed by Soula and Chauzy [1997], i.e., a conductor isolated from the ground and shielded with a grid connected to ground (Figure 2). The grid is a $7.6 \times 7.6 \mathrm{~cm}^{2}$ square mesh and it covers now a cylindrical tank that contains the big funnel-shaped conductor. The sensor does not contain any sharp part to avoid corona emission below thunderstorm electric field conditions. The shielding effect is improved as compared to the previous sensor where the sides were constituted with the grid. However, this effect is not $100 \%$ efficient and therefore very large displacement currents corresponding to lightning flashes can be expected on the current detection. The total height of the sensor is now $0.8 \mathrm{~m}$ while that of the funnel is about $0.6 \mathrm{~m}$. The theoretical efficiency for the raindrops by considering a vertical fall is not different since it is linked to the mesh of the grid. A previous study showed an efficiency of $84 \%$ for very large and rare drops $(5 \mathrm{~mm}$ in diameter) and better for smaller drops. The effective surface of the sensor for the current intensity measurement is that of the funnel-shaped conductor and corresponds to $0.2 \mathrm{~m}^{2}$. This conductor was linked to a Keithley electrometer (used in the current measurement function). The data were recorded on a PC system with a 20-ms time resolution. The polarity conventions for the electric field and the precipitation current density are in agreement with those of MacGorman and Rust [1998]: an upward electric field is positive (as its vertical component), and a positive precipitation current density carries down negative charges.

[8] The third sensor was a disdrometer devoted to the detection of the rain rate and the raindrop size. This apparatus is able to detect and count the number of raindrops of all sizes from 0.2 to $5 \mathrm{~mm}$ in diameter with a $0.2-\mathrm{mm}$ class interval. It calculates the rain rate and the equivalent volumic diameter (EVD) of the raindrops. The EVD for a drop population $\mathrm{N}$ is the diameter $\mathrm{D}_{0}$ of the same number and identical drops that provide an equivalent total water volume V:

$$
\mathrm{D}_{0}=\left(\frac{6 \mathrm{~V}}{\mathrm{~N} \pi}\right)^{\frac{1}{3}}
$$

Both parameters are automatically calculated every minute.

[9] The dynamics of precipitating systems is determined from dual-Doppler observations conducted over the windward slope of the Alps in the Lago Maggiore target area [Bougeault et al., 2001] with the French Ronsard research radar located near Milano at $(45.460 \mathrm{~N}, 8.517 \mathrm{E}, 155 \mathrm{~m}$ MSL) and the Swiss Meteorology Agency operational radar at Monte-Lema (46.042N, 8.833E, $1625 \mathrm{~m}$ MSL). The radar baseline (see Figure 1) was about $70 \mathrm{~km}$ long and was oriented at 20 degrees clockwise from North. The Ronsard operation mode consisted of a sequence of $20360^{\circ}$-azimuth sweeps with azimuthal resolution of $0.62^{\circ}$ and gate spacing of $200 \mathrm{~m}$ along a maximum range of $102.4 \mathrm{~km}$, and at unevenly spaced elevation angles from $0.62^{\circ}$ to $69.43^{\circ}$. The Monte-Lema Doppler scanning mode was composed of two interleaved volume scans of $10360^{\circ}$-azimuth sweeps with azimuthal and radial resolution of $1.0^{\circ}$ and $1000 \mathrm{~m}$, respectively. Maximum radar range was $130 \mathrm{~km}$ and also unevenly spaced elevation angles were used from $-0.3^{\circ}$ to $40.0^{\circ}$. The Doppler-derived wind fields are retrieved through the realtime and automated multiple-Doppler analysis method (RAMDAM; Chong et al. [2000]) for IOP 5 and through the multiple analytical Doppler (MANDOP) analysis [Tabary and Scialom, 2001] for IOP 2A. Explicit smoothing of the retrieved wind components is performed in RAMDAM through the minimization of their second-order horizontal derivatives that is controlled by a prescribed cutoff wavelength, which is fixed as $8 \mathrm{~km}$ in the present study, with a grid resolution of $2 \times 2 \times 0.5 \mathrm{~km}^{3}$. Because MANDOP is based on a representation of the components in terms of orthonormal polynomials over the domain of interest, an implicit filtering is realized in which the cutoff wavelength is dependent on the order $n$ of the expansion as $2 L /(n-1)$, where $L$ is the size of the domain. In this study $L=100 \mathrm{~km}$ and $n=8$ yield a cutoff length of $28.6 \mathrm{~km}$. This indicates that the minimum observable scale, i.e., the characteristic scale of variations, is about $7.5 \mathrm{~km}$. Hence, with this 
Table 1. Budget of the Charge Carried by the Rain for Several Events of the MAP Experiment

\begin{tabular}{|c|c|c|c|c|}
\hline \multirow[b]{2}{*}{ Date } & \multicolumn{2}{|c|}{ Duration } & \multicolumn{2}{|c|}{$\begin{array}{l}\text { Charge Density, } \\
\qquad \mathrm{nC} \mathrm{m}-2\end{array}$} \\
\hline & $\begin{array}{l}\text { Positive } \\
\text { Charge }\end{array}$ & $\begin{array}{l}\text { Negative } \\
\text { Charge }\end{array}$ & $\begin{array}{l}\text { Positive } \\
\text { Charge }\end{array}$ & $\begin{array}{c}\text { Negative } \\
\text { Charge }\end{array}$ \\
\hline 17 September IOP2a & $39 \min 7 \mathrm{~s}$ & $39 \min 4 \mathrm{~s}$ & 21312 & -30614 \\
\hline 27 September & $8 \min 0 \mathrm{~s}$ & $50 \mathrm{~s}$ & 2320 & -174 \\
\hline 30 September IOP 4 & $4 \mathrm{~min} 12 \mathrm{~s}$ & $7 \mathrm{~min} 52 \mathrm{~s}$ & 2092 & -3910 \\
\hline 3 October IOP 5 & $12 \min 26 \mathrm{~s}$ & $12 \min 32 \mathrm{~s}$ & 5629 & -4206 \\
\hline 21 October IOP 8 & $16 \min 38 \mathrm{~s}$ & $15 \min 20 \mathrm{~s}$ & 4818 & -3133 \\
\hline Total & $80 \min 23 \mathrm{~s}$ & $75 \min 38 \mathrm{~s}$ & 36171 & -42037 \\
\hline
\end{tabular}

method, convective-scale features of a few kilometers will be smoothed. In particular, convective updraft magnitude would appear somewhat reduced by about $30 \%$. Since the RONSARD radar was operated in coordination with the MonteLema radar on a 15-minute cycle, the three-dimensional (3-D) retrieved wind and precipitation fields that we present at a given time inform us about the mean characteristics of the observed precipitating system around this time.

\section{General Observations}

[10] During the 1999 Mesoscale Alpine Program (MAP) campaign, the electrical measurement system in Ispra was active from 10 September to 27 October. Electrical activity associated with precipitation was recorded during six days over the period. Table 1 summarizes the main observations and establishes the budget of the charge carried by the rain for site 1, where the rainfall was recorded. The IOP is indicated and it is important to note that only a few IOPs are concerned by detectable electrical activity over our site. The parameters indicated in Table 1 for the precipitation charge transfer are the duration and the charge density for both polarities, day by day and cumulated for the whole measurement period. The surface charge density (in $\mathrm{nC} \mathrm{m}^{-2}$ ) is calculated by integrating the electric current density over the corresponding period. For this estimation, only current density values larger than a threshold of $2 \mathrm{nA} \mathrm{m}^{-2}$ are considered. The different events can have various charge distributions between both polarities as for example 17 September and 27 September. Depending on the shower, negative or positive charge can be dominant. For the total, the proportion is calculated in percentage and it reaches $54 \%$ and $46 \%$ for the negative and the positive charge, respectively. It is interesting to compare these percentages to those discussed by Soula and Chauzy [1997] since they also estimated different proportions of positive and negative charges transferred to the ground. These proportions were $65 \%$ and $35 \%$, respectively, according to the observations by Chauzy and Despiau [1980], while they were 63\% and $37 \%$, respectively, in the paper by Soula and Chauzy [1997]. Moreover, in our case, the total duration of a precipitation current density exceeding the threshold is $9361 \mathrm{~s}$ ( 2 hours and $36 \mathrm{~min}$ ). In the case of Soula and Chauzy [1997], this duration was 1 hour and $21 \mathrm{~min}$. These observations are of a great interest because they question the general assumption that attributes a dominant positive charge to the precipitation from thundercells [Rust and Moore, 1974].

\section{Case Studies}

\subsection{Case of 3 October}

[11] In the afternoon of 3 October 1999, during IOP 5, a series of convective cells passed over the site of Ispra. Figure 3 shows the temperature and geopotential fields at $500 \mathrm{hPa}$, as predicted by the European Centre for Medium-

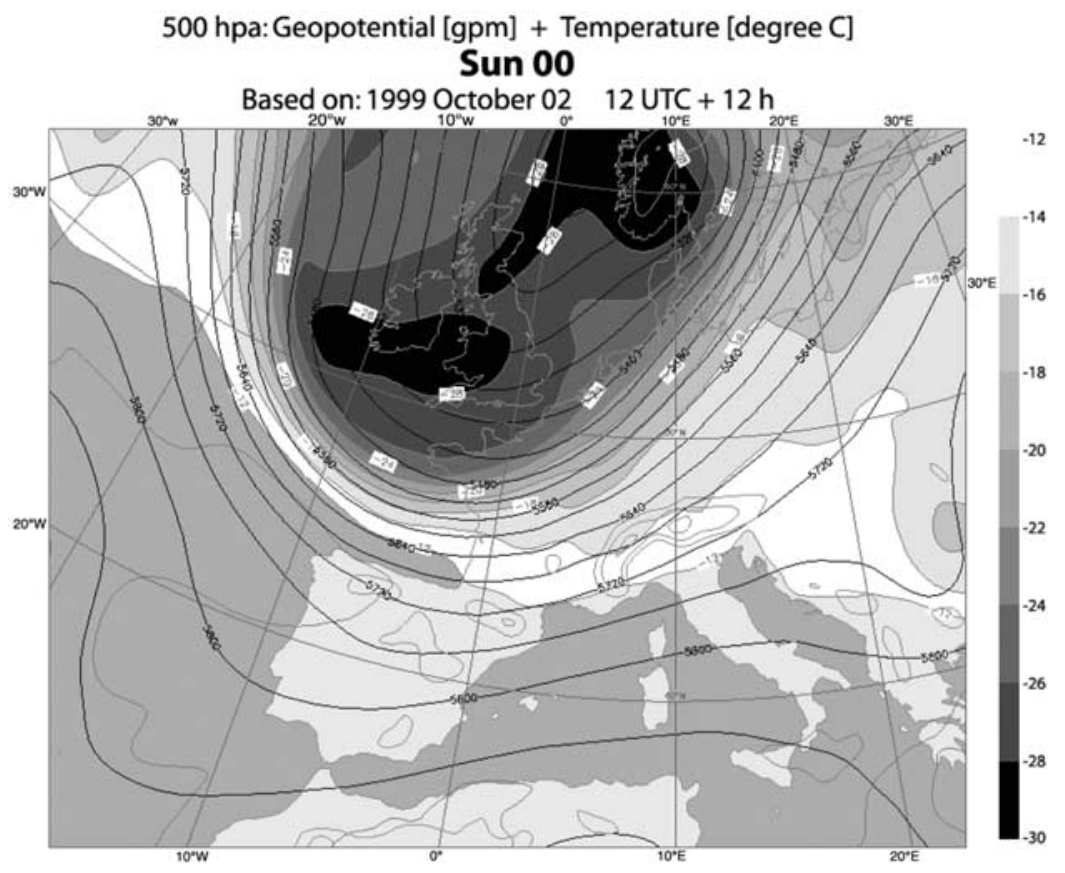

Figure 3. Temperature and geopotential fields at $500 \mathrm{hPa}$ calculated with the model of the European Centre for Medium-Range Weather Forecasts (ECMWF). The forecast is made at 12 hours and corresponds to 0000 UTC on 3 October. 

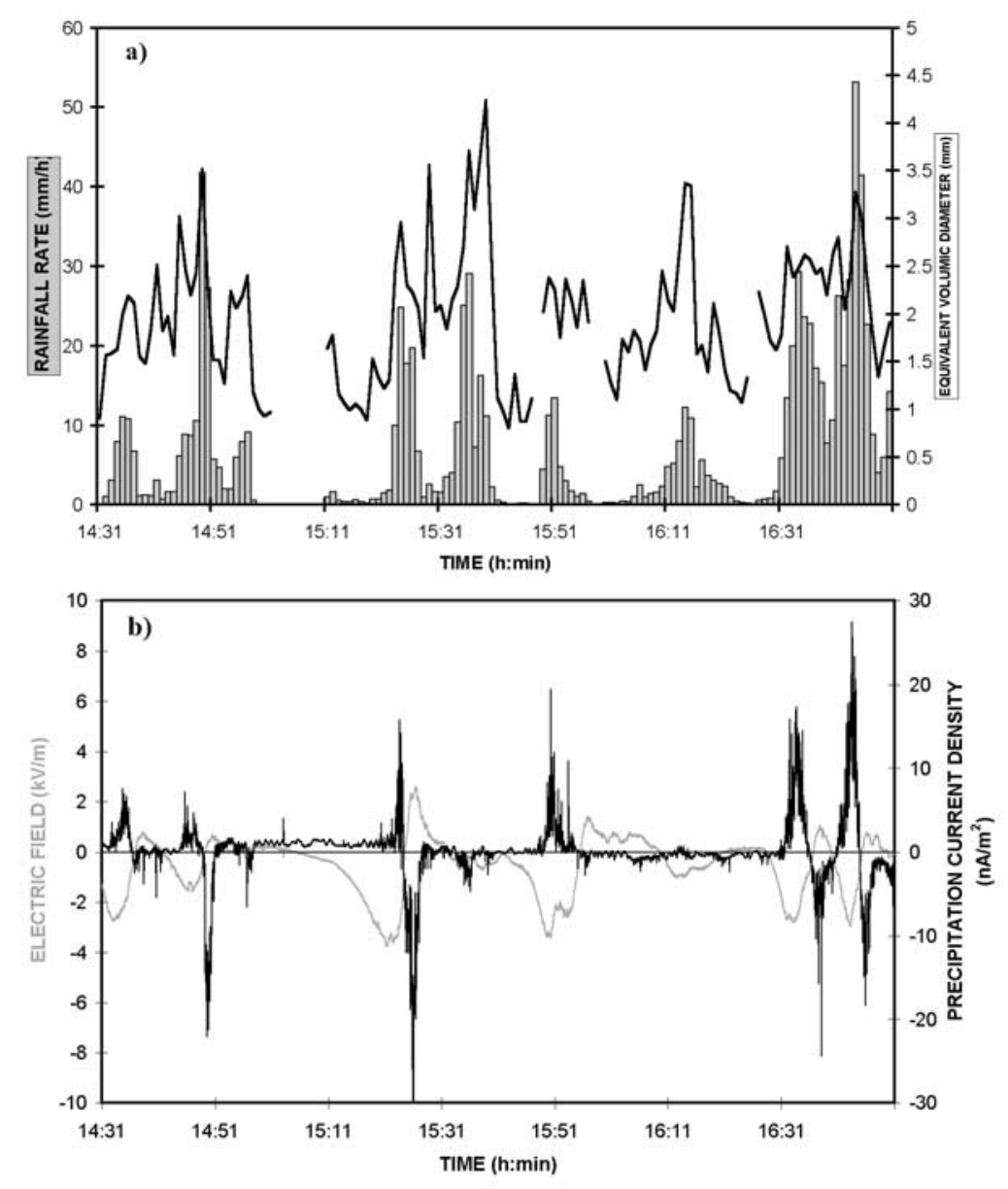

Figure 4. Case of 3 October, recording at the site of Ispra: (a) Evolution of the rain rate in $\mathrm{mm} / \mathrm{h}$ (histogram) and of the EVD in mm (black curve) recorded by the disdrometer. (b) Evolution of the electric field in $\mathrm{kV} / \mathrm{m}$ (grey curve) and of the precipitation current density in $\mathrm{nA} / \mathrm{m}^{2}$ (black curve).

Range Weather Forecasts (ECMWF) model at 0000 UTC on 3 October. A large and deep low located in northwest Europe organized the airflow, which was southwesterly in northern Italy. The air motion around this low led to transport cold air in southern Europe. At lower altitudes, a southerly flow locally occurred because of a convergence with warmer air coming from the east. This pattern could bring instability over the area.

[12] Measurements recorded between 1430 and 1650 UTC are displayed in Figure 4. The rain rate and the EVD recorded at site 1 (Figure 4a) clearly display the showers corresponding to the convective cells observed during the 140-minute period. Each shower lasted several minutes, and the rain rate was quite high since its maximum values ranged from 10 to more than $50 \mathrm{~mm} \mathrm{~h}^{-1}$. The EVD presented similar evolution, and maximum diameter often corresponded to maximum rain rate. However, it is important to note that this diameter did not reach very high values, which means these convective cells did not produce very large drops. When the rain rate was low the EVD ranged between 1 and $1.5 \mathrm{~mm}$, while it reached 3 to $4.5 \mathrm{~mm}$ when the rain rate was maximum.

[13] Figure $4 \mathrm{~b}$ shows the evolution of the electric field and of the precipitation current density for site 1 . This current density is expressed in $\mathrm{nA} \mathrm{m} \mathrm{m}^{-2}$ and it can be either positive or negative during the whole 140-min record. There is a good correspondence between the current detection and the rainfall, i.e., when a current was detected, a rainfall was observed too. From Figures $4 \mathrm{a}$ and $4 \mathrm{~b}$, we can distinguish 8 showers from the rain rate and 6 substantial current density increases. In most cases, the current density started to increase in positive values, and then quickly reversed. In term of carried charge, the charge was first negative and then positive which clearly indicates the bi-polarity of the rain during a thundershower. For 2 out of the 6 showers, around 1435 and 1550 UTC, the bi-polarity was less pronounced. We can also suppose that the whole electrical signature was not detected at the measuring site because of the cell displacement. We observe two showers without any electric current signature or with a very weak one, between 1531 and 1541 UTC and between 1610 and 1620 UTC. However, the rain rates were relatively high at these moments, with maximum values of $30 \mathrm{~mm} \mathrm{~h}^{-1}$ and $12 \mathrm{~mm} \mathrm{~h}^{-1}$, respectively. This observation is related to a more detailed study made from the Doppler radar observations and presented in the following.

[14] In the cases of cells producing a substantial precipitation current with a reverse of its polarity, the maximum of 

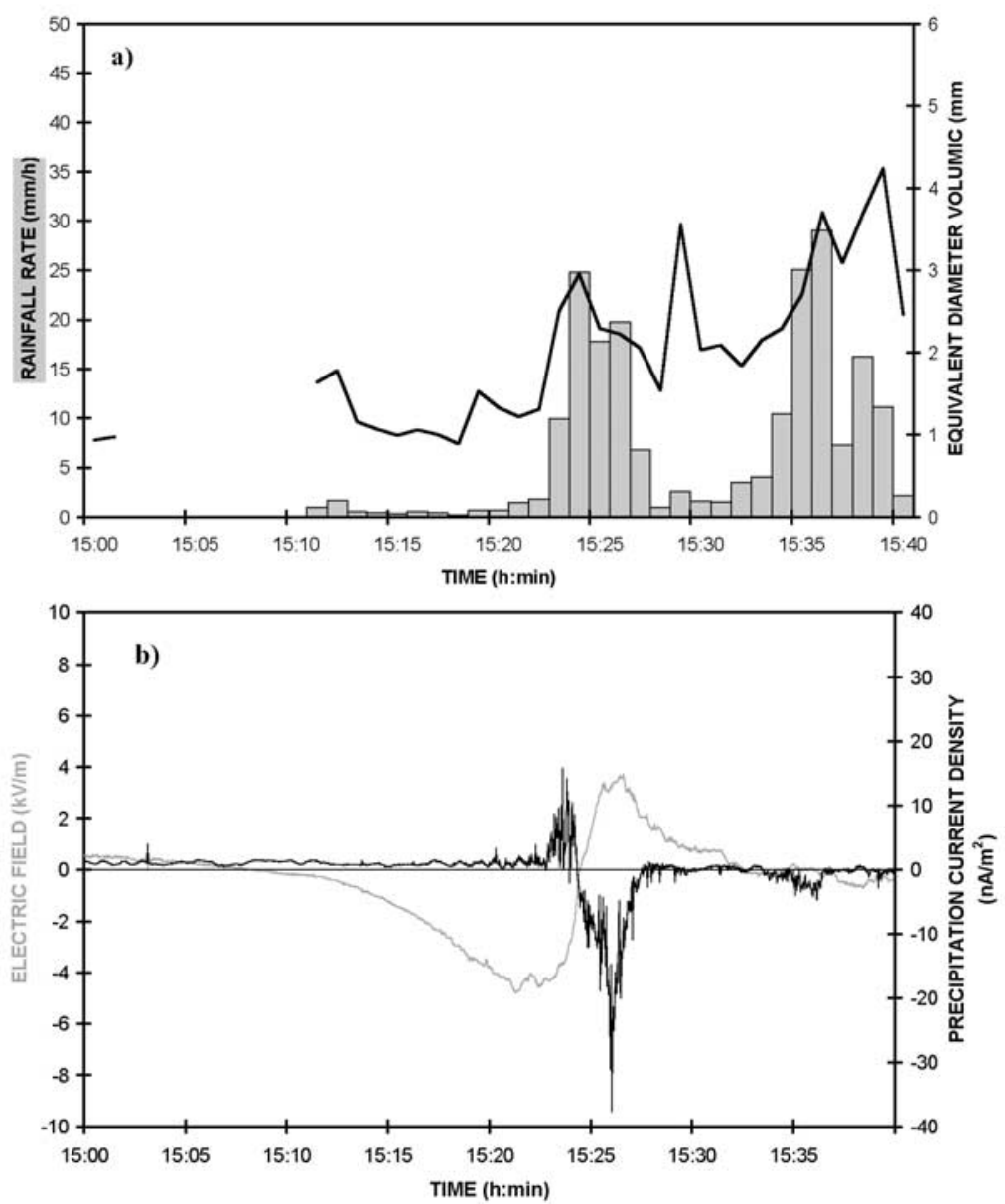

Figure 5. Case of 3 October, recording at the site of Ispra during the passage of two convective cells: (a) Evolution of the rain rate in $\mathrm{mm} / \mathrm{h}$ (histogram) and of the EVD in mm (black curve) recorded by the disdrometer. (b) Evolution of the electric field in $\mathrm{kV} / \mathrm{m}$ (grey curve) and of the precipitation current density in $\mathrm{nA} / \mathrm{m}^{2}$ (black curve).

the rain rate frequently corresponded to this reverse. For example, at $1436,1449,1524$, and 1644 UTC with a rain rate of $11,42,25$, and $53 \mathrm{~mm} \mathrm{~h}^{-1}$, respectively. The reverse of the current density was generally rapid. Very low values of the precipitation current with a high rain rate can be explained either by uncharged drops or by a bipolar and balanced drop population. A previous study showed that the zero crossing of the current generally corresponded to that of the individual charges of the raindrops too [Coquillat et al., 2001].

[15] Figure 5 displays the evolution between 1500 and 1540 UTC of the rain rate (Figure 5a), of the electric field and of the precipitation current density (Figure $5 \mathrm{~b}$ ). Figure $5 \mathrm{a}$ shows two convective cells around 1525 UTC and 1536 UTC, respectively. For the first one, the rain started at about $1521 \mathrm{UTC}$ and reached $25 \mathrm{~mm} \mathrm{~h}^{-1}$ later. Figure 6 illustrates the presence of the cell travelling toward the site (coordinates $25 ; 25$ ) within a predominantly southerly flow and displays its main characteristics in terms of vertical development, reflectivity and dynamics around 1515 UTC. The cell reflectivity core $(>32 \mathrm{dBZ})$ was some kilometers south from the site (Figure 6a). The top of the cloud was between 5 and $6 \mathrm{~km}$ while the vertical air speed was larger than $1.5 \mathrm{~m} \mathrm{~s}^{-1}$ slightly at the rear of the core (Figures $6 \mathrm{c}$ and 6d) with larger values at the eastern side of the system (Figure 6b). When this cell approached the site, the electric field progressively decreased in negative values down to $-4.5 \mathrm{kV} \mathrm{m}^{-1}$ (Figure $5 \mathrm{~b}$ ) and then, increased simultaneously with the arrival of the rain. It rapidly reversed when the rain rate was maximum at $1524 \mathrm{UTC}$ and it reached $+4 \mathrm{kV} \mathrm{m}^{-1}$ before slowly decreasing. We can reasonably observe that there is a relation between the arrival of the rain at the surface and the reverse of the electric field but we have to explain this relation. There is a symmetrical behavior of the electric field before and after the reverse. The global charge responsible for the electric field was therefore first positive and second negative. As soon as the rain was detected at the site, a positive precipitation current was detected, corresponding to negatively charged drops and then, it reversed too, simultaneously to the electric field (Figure $5 b$ ). The mirror image was perfectly described. The negative rain was less charged with a maximum current density close to $15 \mathrm{nA} \mathrm{m}^{-2}$ as compared to the positive rain with a minimum current density close to $-35 \mathrm{nA} \mathrm{m}^{-2}$. Furthermore, the duration of the positive rain was larger. Since the rain rate was similar for both sequences (around $20 \mathrm{~mm} \mathrm{~h}^{-1}$ ), as was the electric field evolution (in absolute value), we can think that the charges on 

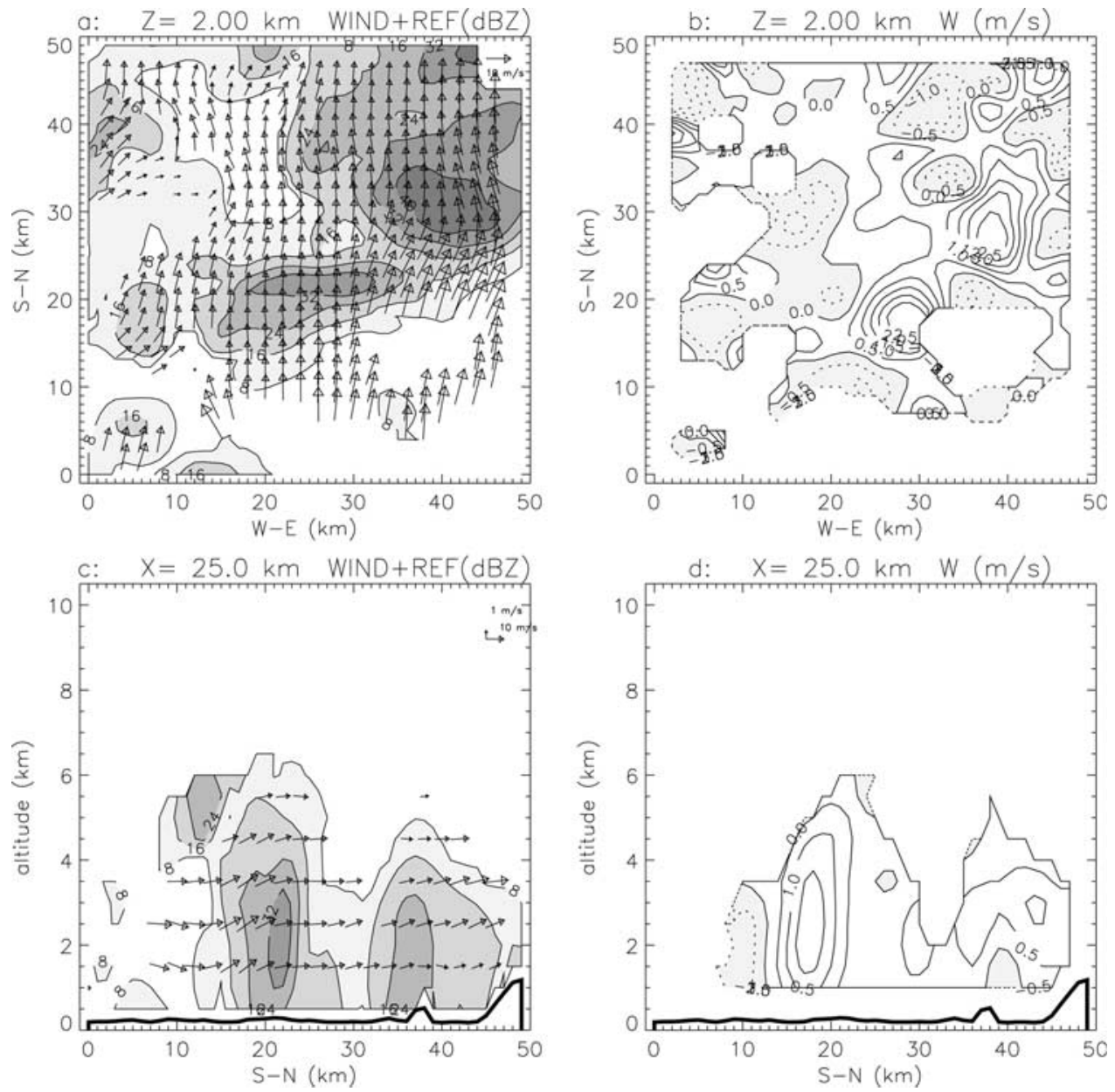

Figure 6. Case of 3 October: 3-D precipitation and wind fields around 1515 UTC for the domain depicted in Figure 1. (a) Horizontal cross-section at $2 \mathrm{~km}$ altitude through the 3-D retrieved wind field (scale in the upper right) superimposed on the radar reflectivity values (contours every $5 \mathrm{dBZ}$ ); (b) associated contours of vertical wind component (every $0.5 \mathrm{~ms}^{-1}$ ). (c) Wind and reflectivity for the meridian cross-section at $\mathrm{X}=25 \mathrm{~km} ;(\mathrm{d})$ associated vertical velocity contours. In Figures $6 \mathrm{a}$ and $6 \mathrm{~b}$ the site of Ispra is in the center $(25 ; 25)$.

the raindrops were not the result of the capture of corona ions as suggested by Simpson [1949]. As a matter of fact, according to this mechanism, and in same conditions of rain and absolute electric field, the precipitation current of both polarities should be equivalent.

[16] The evolution of the electric field produced by most of other showers was the same: a slow decrease in negative value, a rapid reverse to positive polarity and a slow decrease from the positive maximum. An example is given by two consecutive showers between 1630 and 1650 UTC (Figure 4). Figure 7 displays the $3-\mathrm{D}$ wind and precipitation field deduced from RAMDAM around 1635 UTC. Figures 7a and $7 \mathrm{~b}$ are horizontal cross sections of the reflectivity factor and of the vertical velocity, respectively. Figures $7 \mathrm{c}$ and $7 \mathrm{~d}$ are south-north vertical cross sections of the same parameters through the ISPRA site. The cell arrived at the site around 1635 UTC in a southerly flow of about $50 \mathrm{~km} \mathrm{~h}^{-1}$ and it produced two successive rainfalls with rain rates reaching 30 and $55 \mathrm{~mm} \mathrm{~h}^{-1}$ (see Figure 4a), respectively. Its vertical development reached around $6 \mathrm{~km}$ and the reflectivity core locally exceeded $40 \mathrm{dBZ}$ (Figure 7c). The average vertical velocity reached large values: $2.5 \mathrm{~m} \mathrm{~s}^{-1}$ at about $4 \mathrm{~km}$ altitude (Figure 7d). Substantial electric field and precipitation current were recorded, with the same chronology than for the previous cells. There again, the mirror image effect was quasi permanent, and we can note that the precipitation current crossed zero several times while the rain rate was rather high with values above $10 \mathrm{~mm} \mathrm{~h}^{-1}$ (Figure 4b). The electric field and the precipitation current reversed with very short time lags, only a few seconds. So, it confirms the difficulty to interpret the polarity change of the charge carried by the precipitation in terms of Wilson capture of corona ions produced from the ground irregularities. As a matter of fact, after the field and corona ions reverse, by capturing the new ions the drops should need more time to change the sign of their charge. Typically, a duration of a few tens of seconds is necessary [Whipple and Chalmers, 1944].

[17] In Figure 5, we can observe another cell producing a high rain rate around 1535 UTC without any substantial electrical activity. This case justifies an analysis from the radar data shown in Figure 8. As in Figure 7, it displays the 

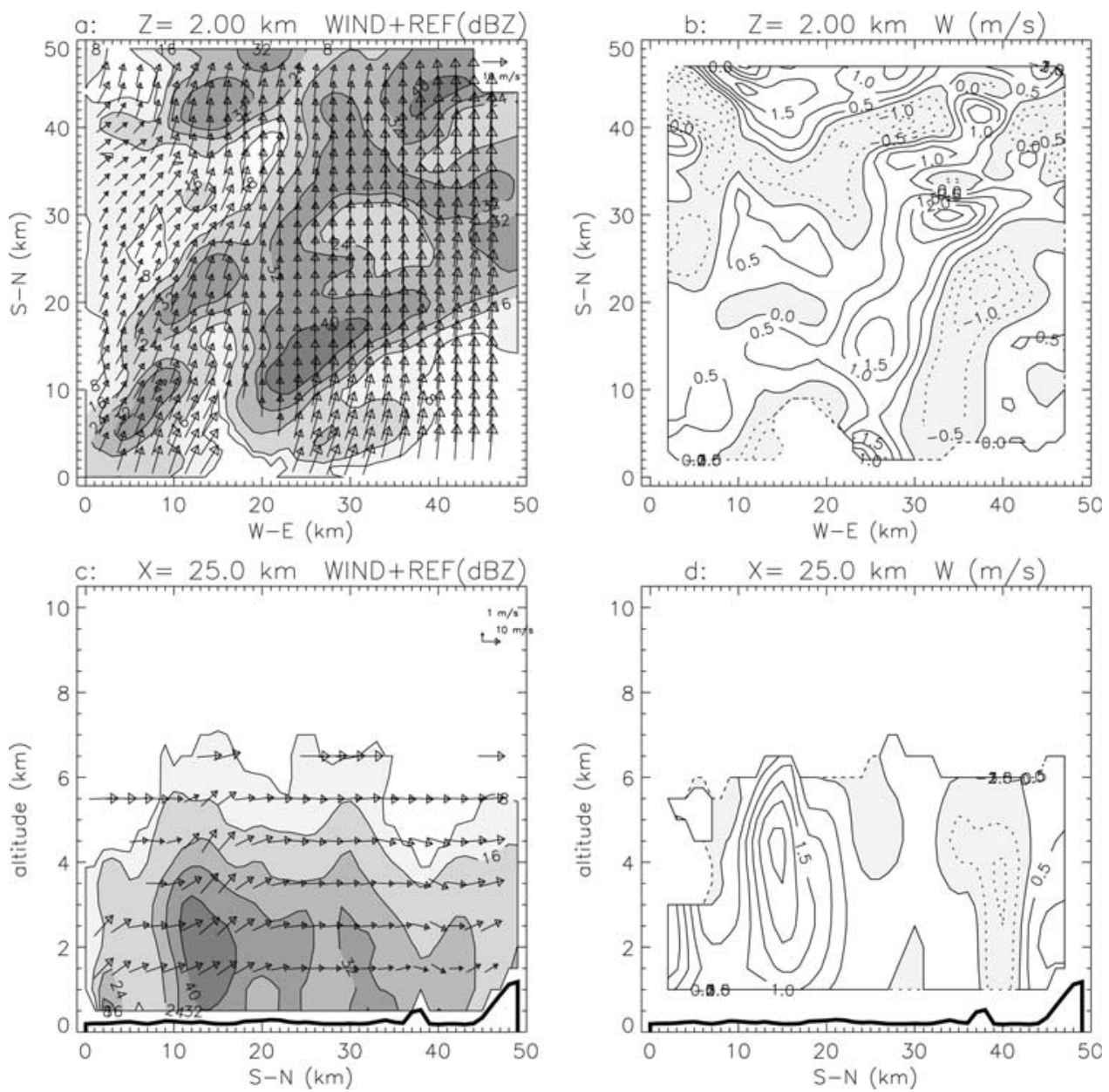

Figure 7. Same as in Figure 6 but around 1635 UTC.

3-D wind and precipitation field deduced from RAMDAM but around 1530 UTC, with west-east and south-north vertical cross sections through the site position (Figures $8 \mathrm{e}$ and $8 \mathrm{f}$ ). The cell located above the site in a southerly flow was quite visible from this set of graphs. The cell top was between 5 and $6 \mathrm{~km}$ of altitude, the maximum of reflectivity exceeded $32 \mathrm{dBZ}$, and the maximum of the vertical velocity was rather weak (around $0.5 \mathrm{~m} \mathrm{~s}^{-1}$ ) even if the structure of the precipitation displayed a convective character. It is interesting to compare it with the cells previously described and having a remarkable electrical signature associated with comparable vertical developments (Figures 6 and 7). In these previous cases, the vertical velocity reached more than $1.5 \mathrm{~m}$ $\mathrm{s}^{-1}$ and $2.5 \mathrm{~m} \mathrm{~s}^{-1}$, respectively, over several kilometers of height. Another cell with no electrical activity can be observed around 1615 UTC (Figure 4). This cell produced rain rates up to $12 \mathrm{~mm} \mathrm{~h}^{-1}$, while the electric field did not vary much and the precipitation current remained close to zero. Figure 9 displays the same characteristics as Figure 8 for this cell. In this case also, the vertical velocity was weak, since the maximum reached $0.5 \mathrm{~m} \mathrm{~s}^{-1}$, while the vertical development and the reflectivity reached $5 \mathrm{~km}$ in altitude and $40 \mathrm{dBZ}$, respectively.

[18] The measured electric field intensity depends very much on the local environment, including the geometry of the sensor [Standler and Winn, 1979; Chauzy and Soula,
1987]. In our case, the electric field was measured on the flat roof of a building, and therefore it could be enhanced by such a geometry. The building being also surrounded by high trees, we cannot exactly know the real modification of the electric field by the environment as compared to that existing at the flat ground level around the building. We should therefore be more attentive to the field evolution than to its absolute value during the analysis. Anyway, the field evolution was very similar at both sites, which means that the environment probably did not play a major role in the field evolution. The electric field polarity was very often opposed to that of the precipitation current density. So, when the precipitation current was positive, the electric field was negative, i.e., downward or created by positive charges above, and vice versa. The typical behavior of the evolution of both parameters when a thundercell was approaching is well illustrated for example at 1431, 1515, 1545 or 1630 UTC in Figure 4. In these sequences, the electric field began to slowly decrease toward negative values, then the precipitation started and carried a dominant negative charge, and finally the electric field and precipitation current density rapidly and quasi simultaneously reversed.

\subsection{Case of 17 September}

[19] On 17 September (IOP 2A) a very active system associated with a squall line crossed the experimental zone 

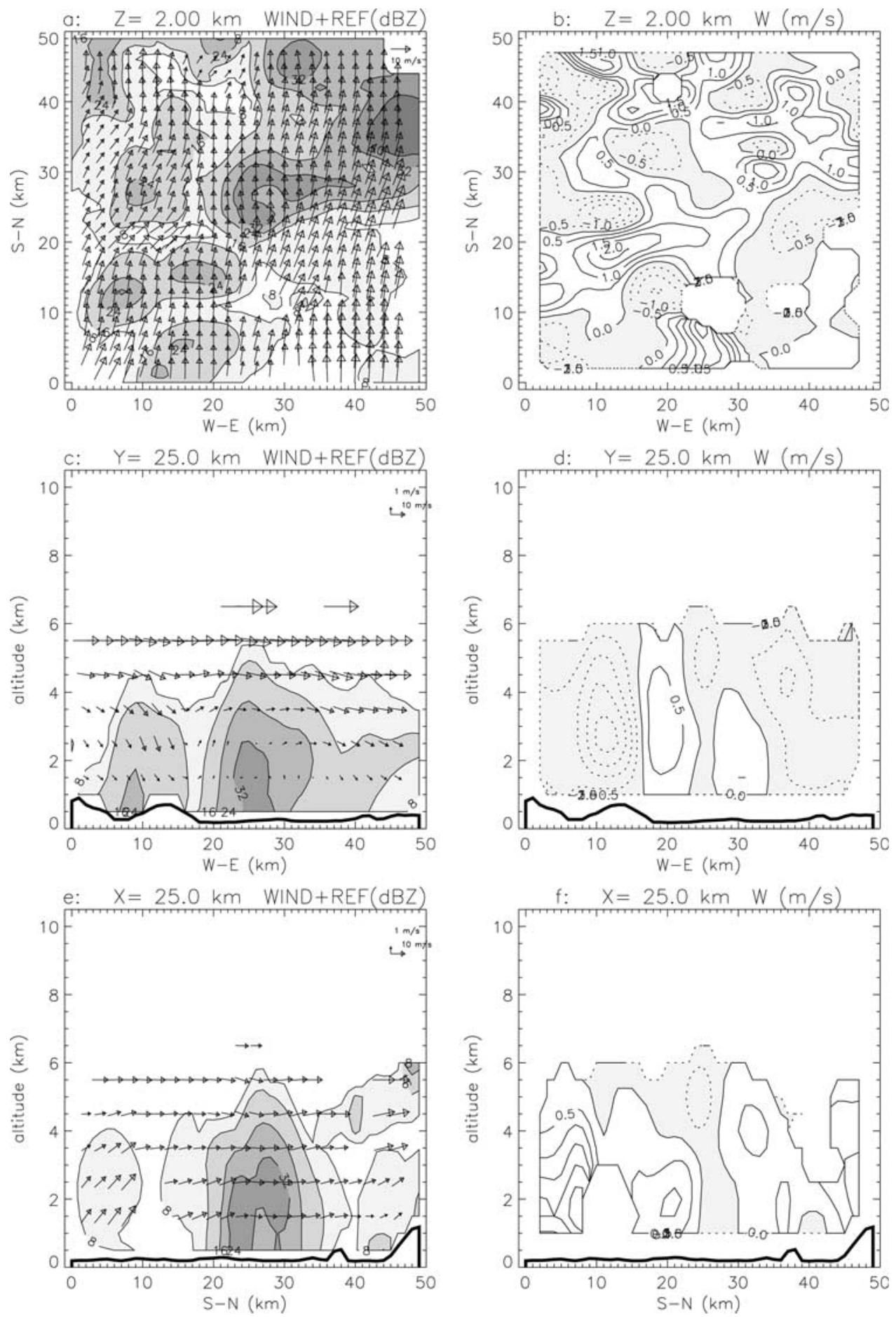

Figure 8. (a-d) Same as in Figure 6 but around 1530 UTC. (e) Wind and reflectivity for the longitudinal cross-section at $\mathrm{Y}=25 \mathrm{~km}$; (f) associated vertical velocity contours.

in the Lago Maggiore area. Figure 10 illustrates the situation of that day. It corresponds to the ECMWF forecast at 0600 UTC on 17 September and displays the geopotential and temperature fields at $500 \mathrm{hPa}$. A large-scale low pressure was located to the west of the British Islands. The associated flow from southwest in southern Europe was not strong. Several undulations of the geopotential lines and temperatures occurred, especially one above southeastern France at the forecast time providing cold air in altitude.
The thunderstorms observed at the end of the day of 17 September in the Ispra area developed ahead of this cold front.

[20] Figure 11 displays the different evolution of precipitation parameters (Figure 11a) and electrical parameters (Figures $11 \mathrm{~b}$ and $11 \mathrm{c}$ ). These evolutions lasted 1 hour and included the signature of an especially strong thunderstorm. As a matter of fact, according to Figure 11a the rain rate averaged over 1 minute periods reached $195 \mathrm{~mm} \mathrm{~h}^{-1}$ at 

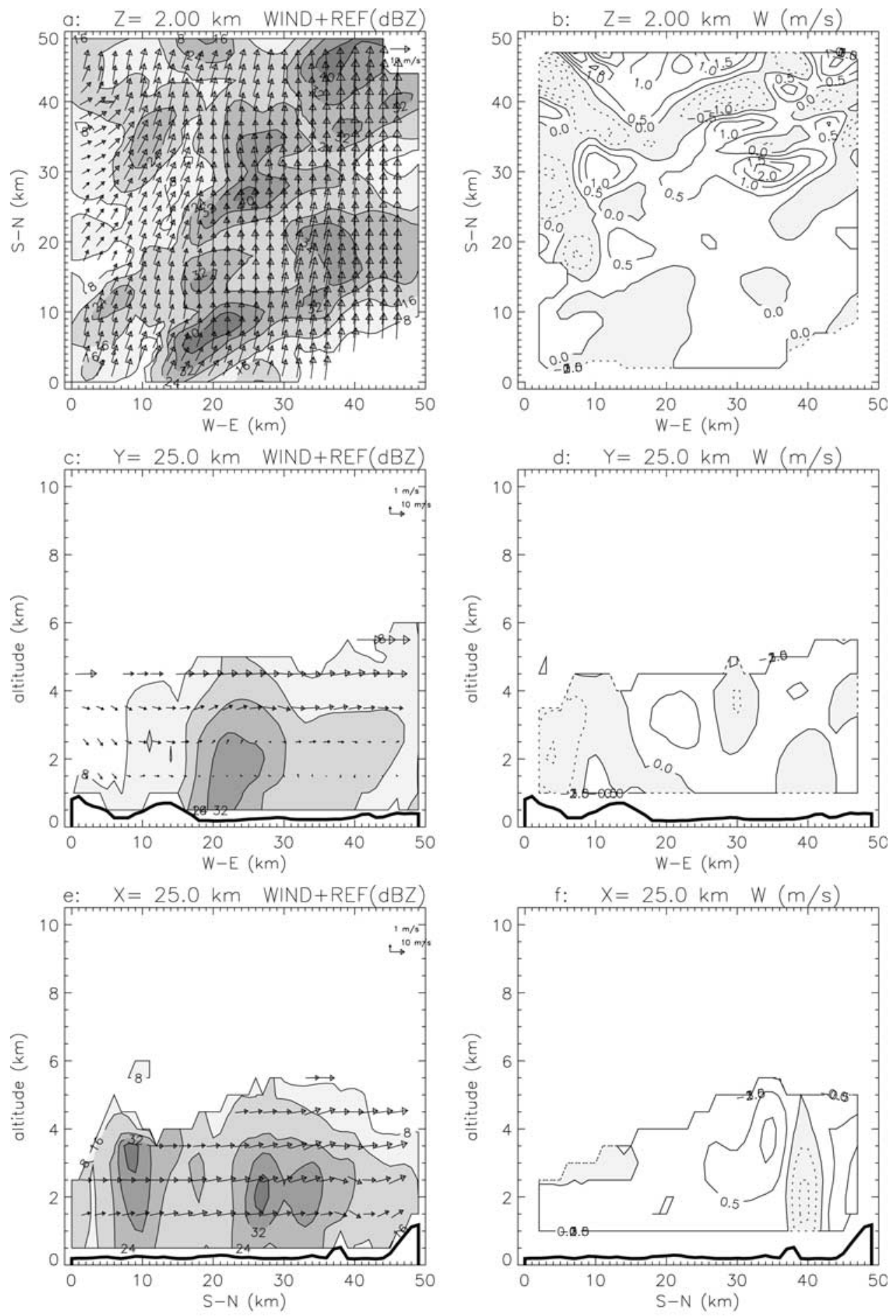

Figure 9. Same as in Figure 8 but around 1620 UTC.

1959 UTC after a progressive increase during about $20 \mathrm{~min}$. The EVD was maximum at the beginning of the precipitating period with a very large value exceeding $5 \mathrm{~mm}$, while it was close to $4 \mathrm{~mm}$ at $1955 \mathrm{UTC}$. This indicates that the largest drops reached the ground first. The decrease of this rate was especially rapid after the maximum of 1959 UTC.

[21] The precipitation current density simultaneously detected with the precipitation rate is displayed in Figure 11b. Many impulses appear along this evolution, because the shielding effect of the current sensor (section 2) was not total and this sensor partially detected large displacement currents produced by the electric field changes associated with the lightning flashes. Their polarity corresponds to the field change reported in Figure 11c. Both polarities occurred during the total evolution, first the positive one between 1940 and 1958 UTC and the negative one after the maximum of the precipitation rate between 1958 and 2005 UTC. During this first phase the precipitation current 


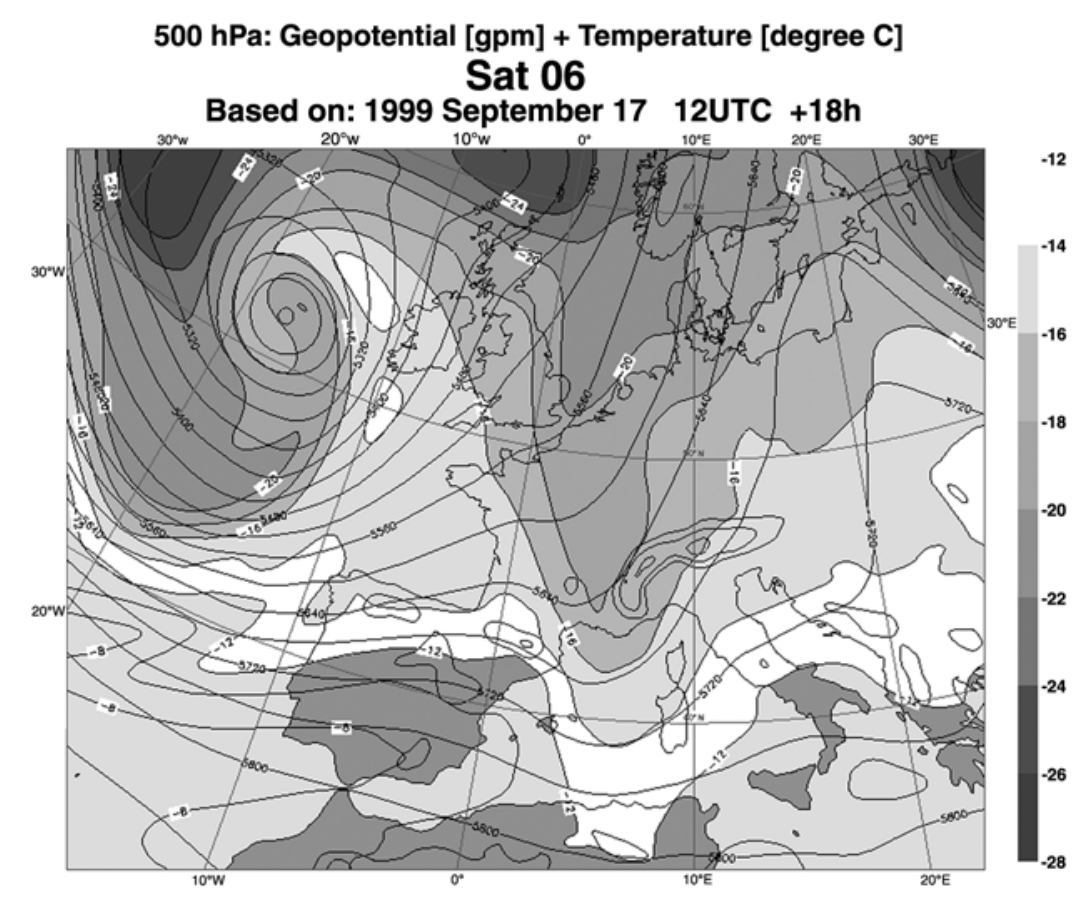

Figure 10. Same as Figure 3. The forecast is made at 18 hours and corresponds to 0600 UTC on 17 September.

underwent slight negative excursions during short periods corresponding to decreases. So, the maxima of rain rate did not correspond to the maxima of precipitation current but rather to its reverses like at 1953 and 1959 UTC. The density of this current reached very large values, close to $100 \mathrm{nA} \mathrm{m}^{-2}$ in positive values. A new reverse was observed after 2005 UTC, while the rain rate was quite low and progressively decreased.

[22] As indicated in Figure 11c, the electric field was always large during the sequence and its variation was characterized by a lot of discontinuities classically produced by lightning flashes. The rate of lightning flashes is so high that it is difficult to count them from Figure 11c. Actually, the activity was so strong in the whole area that some small discontinuities could be due to other thundercells. At the beginning of the recording before the rain reached the ground at the site, the electric field was high with values close to $5 \mathrm{kV} \mathrm{m}^{-1}$. This type of evolution is typical of the thunderstorm activity [Moore and Vonnegut, 1977; Standler and Winn, 1979; Chauzy and Soula, 1987]. Before the rainfall started, the electric field presented both polarities and slowly changed from one to another. This slow change can be interpreted as the change in the polarity of the dominant charge above. After 1940 UTC, the electric field progressively changed from positive to negative; that is, the associated charge also varied but from negative to positive. A new reverse of the electric field was observed just before 2000 UTC when the precipitation current reversed. So, the mirror image effect between both parameters was mostly observed. The values reached by the electric field were not very high, but the precipitation parameters reached exceptionally high values in terms of rain rate and current density. In fact, the field reached the classical limit between flashes by slow variation $\left(<10 \mathrm{kV} \mathrm{m}^{-1}\right.$ in absolute value), even for this very strong thunderstorm. This observation was con- sistent with those made by other authors about the stabilization of the surface electric field above land [Gunn, 1954; Standler and Winn, 1979; Soula and Chauzy, 1991].

[23] Figure 12 shows two horizontal cross sections at 2010 UTC of the reflectivity factor and wind fields, at $3 \mathrm{~km}$ and $6.9 \mathrm{~km}$ of altitude, respectively. The domain is now different from the previous cases since it is $100 \times 100 \mathrm{~km}^{2}$ and the site of Ispra corresponds to the coordinates $(46 ; 47)$ in this new domain. Two cores of reflectivity reaching $55 \mathrm{dBZ}$ at both altitudes were visible, one in the southsoutheast of the site and the other in the southwest. Since the flow was roughly southwesterly or westerly, these cores stayed south of the site during the system displacement. The main core ahead of the system was closer to the site a few minutes before, which is coherent with the evolutions reported in Figure 11. The ground impacts of the cloudto-ground (CG) lightning flashes of both polarities are indicated in Figure 12 during the 15-minute period between 2000 and 2015 UTC. We can distinguish two zones, one with dominant negative $\mathrm{CG}$ flashes in the southwestern part of the cell and the other with dominant positive ones in the north eastern part. Two vertical cross sections of the reflectivity factor and of the airflow vectors are also displayed in Figure 13. They show the strong development of this cell, with reflectivities larger than $50 \mathrm{dBZ}$ up to $10 \mathrm{~km}$ in altitude. On the other hand, these high reflectivities were very close to the ground and indicated strong rain rates close to the site. Strong updrafts were located in the upper part of the cell associated with large reflectivities but also out of this part in the northern direction (Figure 13d). The increase of the positive CG flash production at the end of the storm activity has been frequently reported [Fuquay, 1982] but they can occur during the mature stage of the severe storm and emanate from several regions of the cloud [Rust et al., 1981]. In the present case, the positive CG flash 

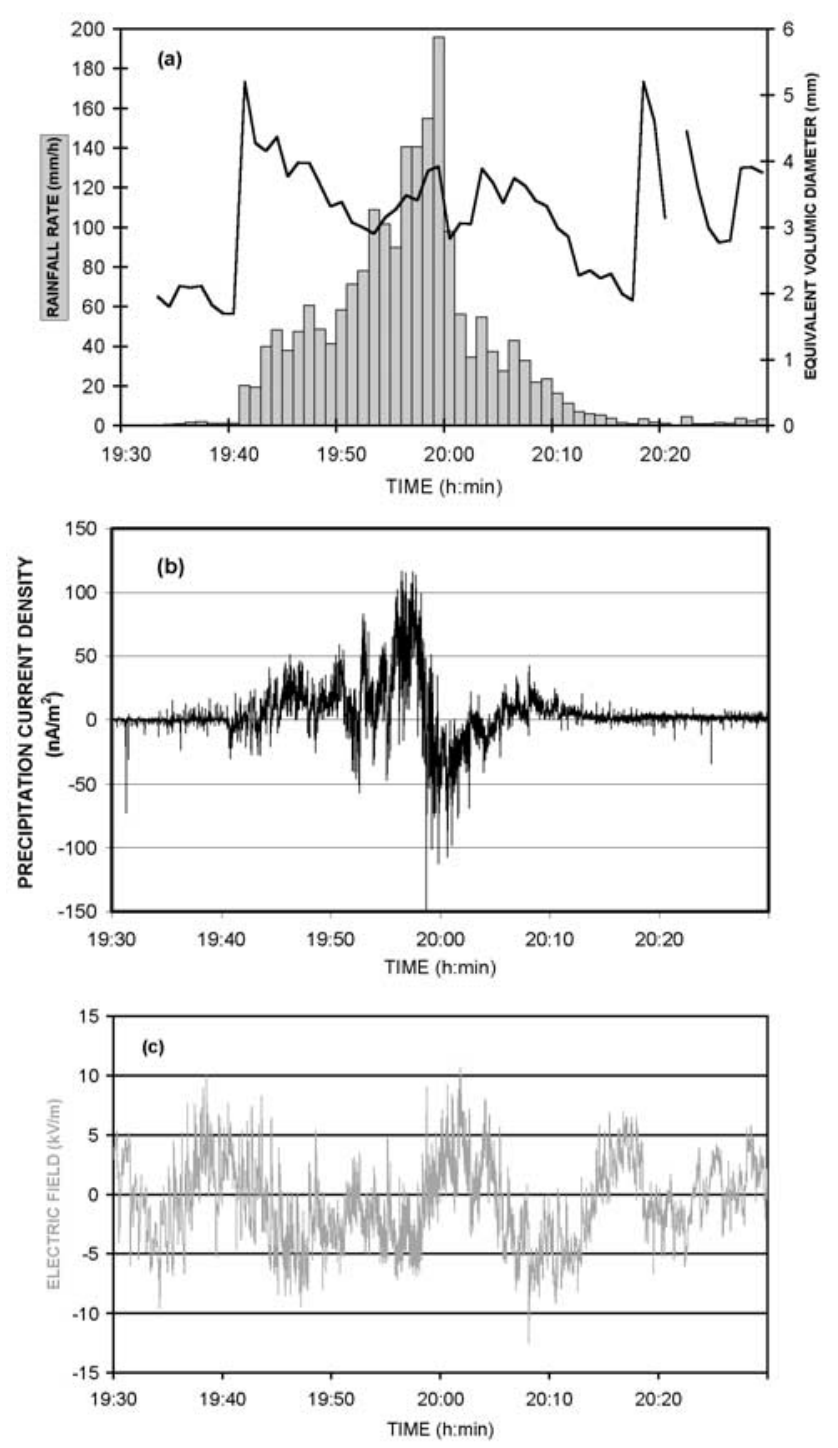

Figure 11. Case of 17 September, recording at the site of Ispra during the passage of the deeply convective cell: (a) Evolution of the rain rate in $\mathrm{mm} / \mathrm{h}$ (histogram) and of the EVD in mm (black curve) recorded by the disdrometer. (b) Evolution of the precipitation current density in $\mathrm{nA} / \mathrm{m}^{2}$. (c) Evolution of the electric field in $\mathrm{kV} / \mathrm{m}$.

production increase was not typical of the dissipating phase of the storm because at that moment the dynamics of the cell presented strong vertical motions. Such an observation agrees with others about positive CG-producing severe storms [Seimon, 1993; MacGorman and Burgess, 1994; Carey and Rutledge, 1998].

\section{Discussion}

[24] The global study indicates that the negative charge carried down to the ground by the precipitation was larger than the positive one, in agreement with Soula and Chauzy [1997]. However, the proportions are close, $54 \%$ and $46 \%$ for the negative and positive charges, respectively. This result obtained from several thundercells and from a long enough cumulated measurement duration can be considered as an important reference, and it opposes the prevalence of the positive charge on rain arriving at the Earth's surface that was generally admitted [Marshall and Winn, 1982] even if some experimental results display both polarities for this current [Rust and Moore, 1974]. The most remarkable fact is the chronology between both polarities. The negative charge always preceded the positive one during the seven thundercells producing a substantial precipitation current. However, in some cases of thundercells, the charge of the rain remained very low, and in other cases it displayed only one polarity. The electric field and the precipitation current quasi systematically showed the mirror image effect. We have therefore two discussion subjects: the understanding of the relation between electric field and precipitation current, and furthermore, the role of the charge transfer by the precipitation in the thundercloud electrical mechanisms.

[25] The cell of 17 September is largely more active than the other cells in term of lightning flash production, as indicated by the field evolution of Figure 11. However, the electric field values are not much higher than those measured in the cases of 3 October. We know that the surface electric field measured over land is limited at intensities lower than $10 \mathrm{kV} \mathrm{m}^{-1}$ by the point discharge effect [Standler and Winn, 1979; Soula and Chauzy, 1991]. Before the rain reached the site (before 1941 UTC), the electric field increased in positive value. At that moment, the cell produced a lot of lightning flashes and approached the site as indicated by the data of the CG lightning flash detection network and by the 5-minute Monte Lema radar images, respectively. After 1941 UTC, the precipitation current started with substantial values and a positive polarity, the electric field reversed toward negative polarity. It corresponds to the classical observations of the polarity of these parameters produced by a thundercloud [Moore and Vonnegut, 1977]. When the field reversed between 1940 and 1945 UTC, it corresponded to that created by a positive charge above, while the precipitation carried a majority of negative charges. The net reverse of both parameters occurred just before 2000 UTC when the rain rate was maximum. At that moment, the positive CG lightning flash proportion started to increase to reach large values $(66 \%$ at 20:15 UTC) as indicated in Figure 14. As a matter of fact, most positive CG flashes were produced after 2000 UTC while the total CG activity decreased and the positive CG proportion reached $66 \%$ of the total CGs at 2015 UTC. It is a classical observation for the CG flash activity since the simultaneous increase of the positive CG proportion and decrease of the total CG activity at the later stages of the thunderstorm have been pointed out by many other authors [Fuquay, 1982; Orville et al., 1983]. The cell presented a long lifetime and after the 1-hour period considered here, it evolved toward a system more complex by joining other cells to form a line. We do not consider the global lightning activity of the whole system in this specific study devoted to precipitation current characteristics. The simultaneous occurrence of the precipitation peak and of the field transition from positive to negative polarity has been noted by Carey and Rutledge [1996]. These authors, by using multiparameter radar, observed also a maximum of the storm outflow associated with the field increase in negative polarity. The possible interpretation of the polarity change of the surface field at that moment is the charge reversal 

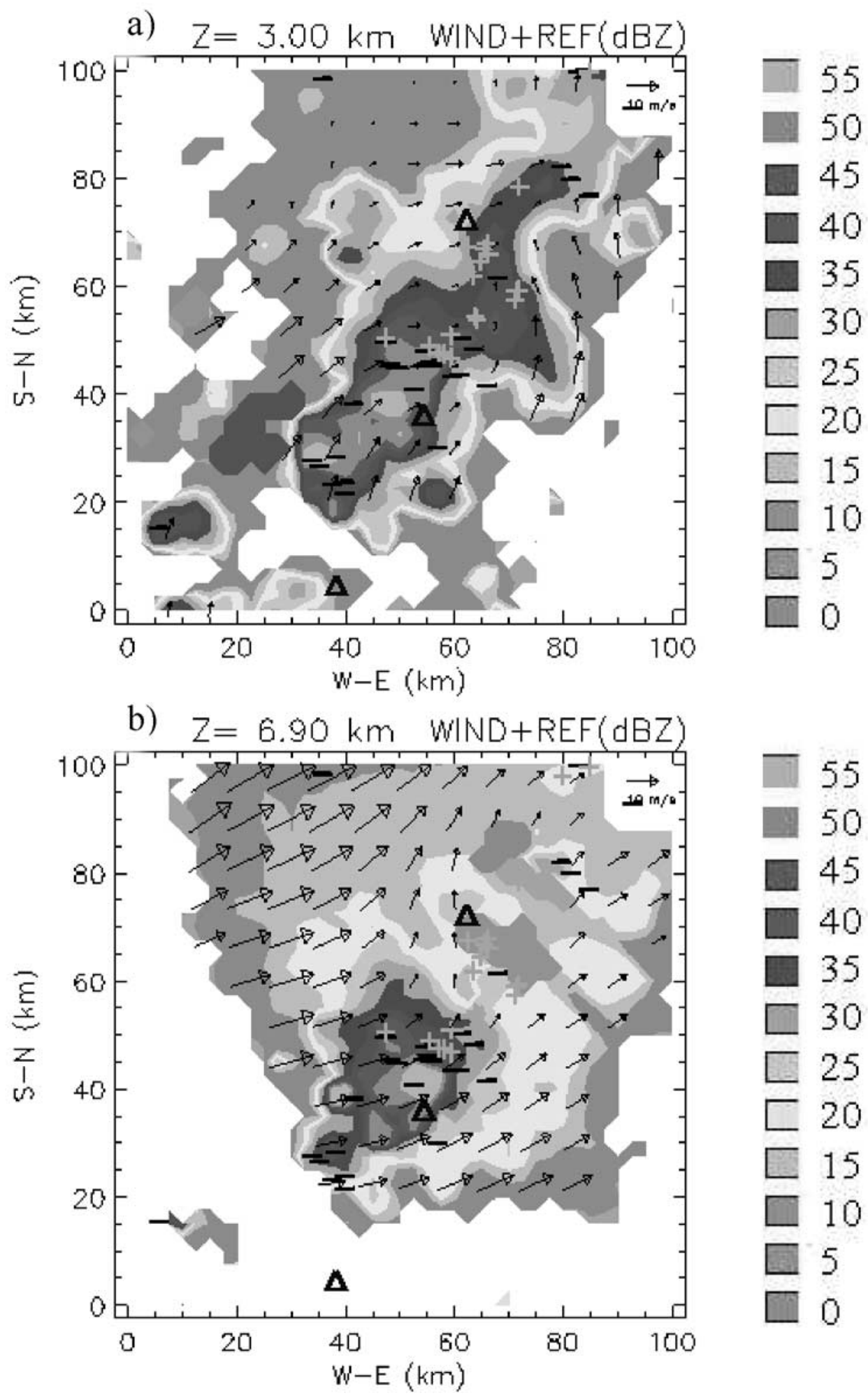

Figure 12. Case of 17 September: 3 -D precipitation and wind fields around 2010 UTC for a $100 \times$ $100 \mathrm{~km}^{2}$ domain with the site of Ispra located at $(46 \mathrm{~km} ; 47 \mathrm{~km})$. Horizontal cross-section at (a) $3 \mathrm{~km}$ and (b) $6.9 \mathrm{~km}$ altitude through the 3-D retrieved wind field scale in the upper right superimposed on the radar reflectivity values (contours every $5 \mathrm{dBZ}$ ). The reflectivity scale in $\mathrm{dBZ}$ is indicated at right. CG lightning flashes are indicated with - and + symbols. Triangles correspond to radar locations. 

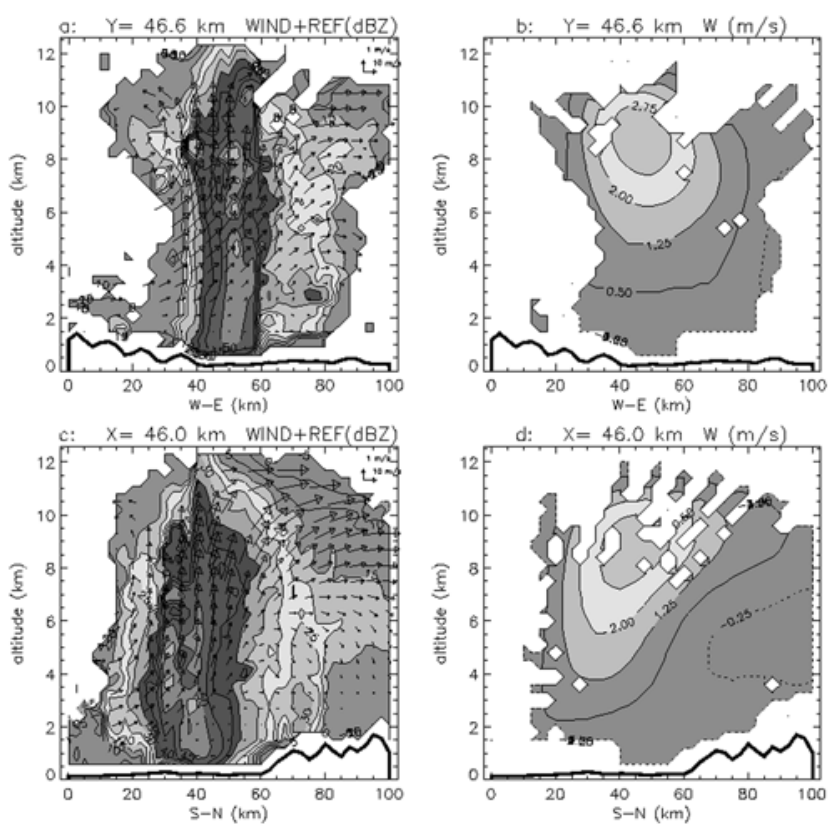

Figure 13. Case of 17 September: Vertical scans of the precipitation and wind fields around 2010 UTC. (a) and (c) Wind and reflectivity for two cross-section at $\mathrm{Y}=46.6 \mathrm{~km}$ and $X=46 \mathrm{~km}$, respectively; (b) and (d) associated vertical velocity contours. The reflectivity scale is same as in Figure 11 and that of the velocity is indicated in $\mathrm{m} \mathrm{s}^{-1}$.

temperature in the noninductive charging process. This phenomenon is also evoked by Lang et al. [2000] in a study of intense convective storms where the negative CG flash rates substantially decreased before the end of the activity. In our case, the simultaneous detection of a positively charged precipitation and of positive $\mathrm{CG}$ flashes could correspond to this interpretation. Another work by Carey and Rutledge [1998] reported observations about a severe storm with high intracloud/cloud-to-ground flash ratio and a high positive CG proportion. According to these authors, the positive $\mathrm{CG}$ flashes were directly associated with light rain adjacent to the main precipitation core. The maximum of the CG flash production of the cell did not correspond to the maximum of rain detected at the site since it occurred around 1935 UTC but at that moment the cell was located more west. We can think that the rain was heavy at this location at that moment because the maximum of CG production is often observed with the arrival of the heavy rain at the ground [Petersen et al., 1996].

[26] On 3 October, six electrically active thundercells passed over the measurement site and for each one, the electric field evolution was characterized by a reverse during the rainfall. This behavior could corresponds to the electric field signature produced by a dipole almost horizontal and traveling above the site. It could also be due to the fall of a vertical dipole, the positive charge zone being topped by the negative one. The problem with this second scheme is that the detected charges carried down by the rain did not correspond to this chronology since the negatively charge rain first reached the surface. A model study is made to support the validity of the first configuration with the passage of two consecutive charges above the site. The rapid reverse of the electric field indicated that the charge producing it rapidly changed and therefore both charge centers were close.

[27] Figure 15 shows the scheme of this physical model. It features two cylindrical-shaped charged zones with opposite volume charge densities $\rho$ and $-\rho$ ( $\rho$ is positive). However, this model cannot directly represent the state of the cloud charge at a given instant. Figure 16a displays the field evolutions measured at both sites. They clearly show a rather symmetrical influence of both charge polarities. The zero crossings are roughly $30 \mathrm{~s}$ apart, which corresponds to the time taken by the cell to travel from site 1 to site 2 . The displacement velocity $50 \mathrm{~km} \mathrm{~h}^{-1}$ in the direction of the sites axis is provided by radar observations and the distance between sites is $600 \mathrm{~m}$. The geometry of the charge volume is an important parameter for the electric field intensity, the

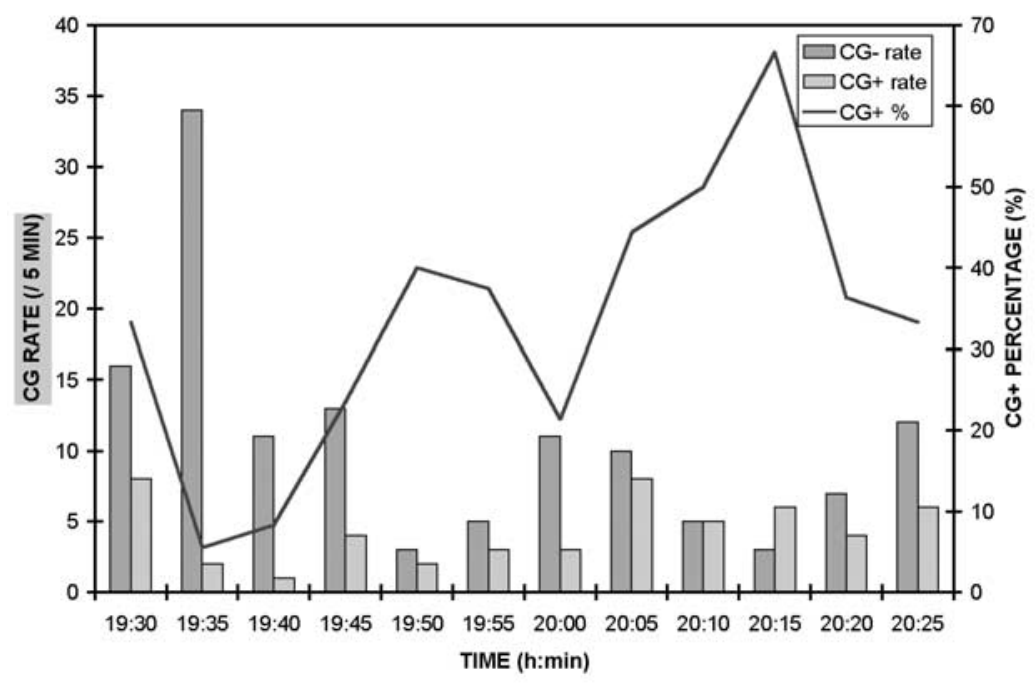

Figure 14. Case of 17 September: Evolution of the CG lightning flash rates (histograms) and of the positive CG proportion (curve) for the thundercell of Figure 11. 


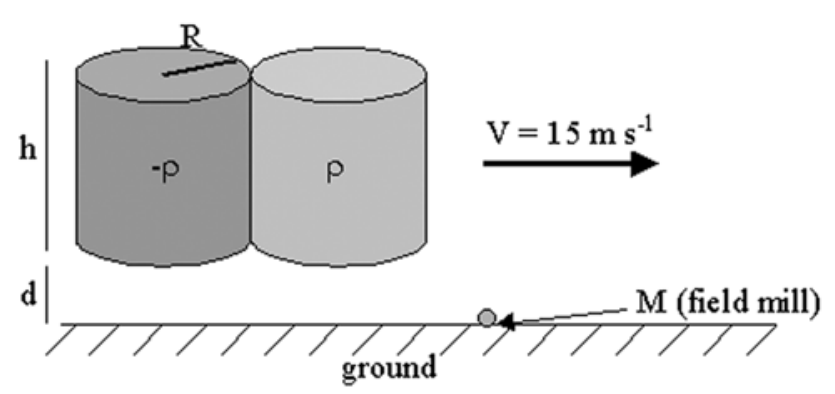

Figure 15. Scheme of the model used for the electric field evolution reconstitution.

base height of the charge volume, the radius of the cylinder and its vertical extend are chosen as 300, 1000 and $3000 \mathrm{~m}$, respectively. The influence of this vertical extent on the surface field is not an important factor because the electric field varies as the inverse of the square distance. In the opposite, the charge density in the volume considered is a very important factor and the chosen value of $5 \times 10^{-9} \mathrm{C} \mathrm{m}^{-3}$ seems to be realistic. This charge density is considered constant in the whole volume and for both charge polarity in absolute value.

[28] The electric field is calculated as the result of the charge distributed in both volumes above a conductive plan. So, the electric field is vertical and its vertical component is twice that created by the real charge. Each cylindrical volume is divided into elements $\mathrm{dV}$ and the total electric field is calculated as the sum of the elementary fields $\mathrm{dE}$ at each time step. The vertical component corresponding to $\mathrm{dE}$ created by the positive charge is negative and equal to:

$$
d E_{z}=-2 \frac{\rho}{4 \pi \varepsilon_{0}} \frac{\mathrm{dV}}{\mathrm{D}^{2}} \cos \alpha
$$

[29] In this expression $\mathrm{V}$ and $\mathrm{dV}$ are the volume and the elementary volume of the cylinder, respectively $(\mathrm{dV}=\mathrm{r} d \mathrm{r}$ $\mathrm{dh} d \theta$, elementary volume in cylindrical coordinates). $\mathrm{D}$ is the distance from the charge element to point $\mathrm{M}$. The angle $\alpha$ is that between the vertical axis crossing the point $M$ and the direction from $\mathrm{M}$ to the elementary volume. The vertical component of the field created by the negative charge is positive and can also be expressed by (1) with the geometry parameters related to the negative charge. The total electric fields created by each cylinder are obtained with an integrate calculation and then finally added. So, the total vertical component is:

$$
E_{z}=2 \iiint_{\mathrm{V}}-\frac{\rho}{4 \pi \varepsilon_{0}} \frac{\mathrm{dV}}{\mathrm{D}^{2}} \cos \alpha+2 \iiint_{\mathrm{V}} \frac{\rho}{4 \pi \varepsilon_{0}} \frac{\mathrm{dV}}{\mathrm{D}^{2}} \cos \alpha
$$

[30] Figure 16b displays the field evolution as calculated by the model. The agreement with experimental evolution is quite good. Different calculations show that the evolution shape of the electric field is the same with a smaller volume and even with two pinpoint charges located within the volumes. Several charge distributions have thus been considered with different volumes and in each case the charge density or value is adapted in order to restitute the experimental field values. Of course, several parameters are arbitrarily chosen to correspond to the observed evolution. We can note however that the observed field evolution requires a horizontal distribution of both charge polarities. In the case of a volumetric distribution of the charge, the transition from one to the other polarity is very rapid. It is also necessary to find a relation between the rain current and this configuration of the charge in the cloud. The polarity of the precipitation current associated with the field evolution could be explained by the loss of charge of polarity in contrast to that of the charge that creates the electric field during the rainfall. In such a scheme the field evolution associated with the precipitation is not due to the approach of the rain charge but to the arrival of this charge at the ground. The electric field observed at the ground is therefore the result of the charge in excess within the cloud. This interpretation is based on an hypothesis made by Marshall and Rust [1991] and Marshall et al. [1995] about the structure of the charge within the thundercloud. They suppose an infinite horizontally extent of the charge. In such conditions, when a large charge layer approaches the ground, the electric field below does not increase. This configuration with two charge distributions, one carried by the rain and transferred to the ground, the other remaining in the cloud, moves horizontally. According the observation made on 3 October, ahead of the convective cell, the charge remaining in the cloud is positive and the charge on the rain is negative. When the field reverse is observed at the site, which often corresponds to the rainfall maximum, the mechanism is probably reversed above, i.e., the charge remaining in the cloud and the charge on the rain are
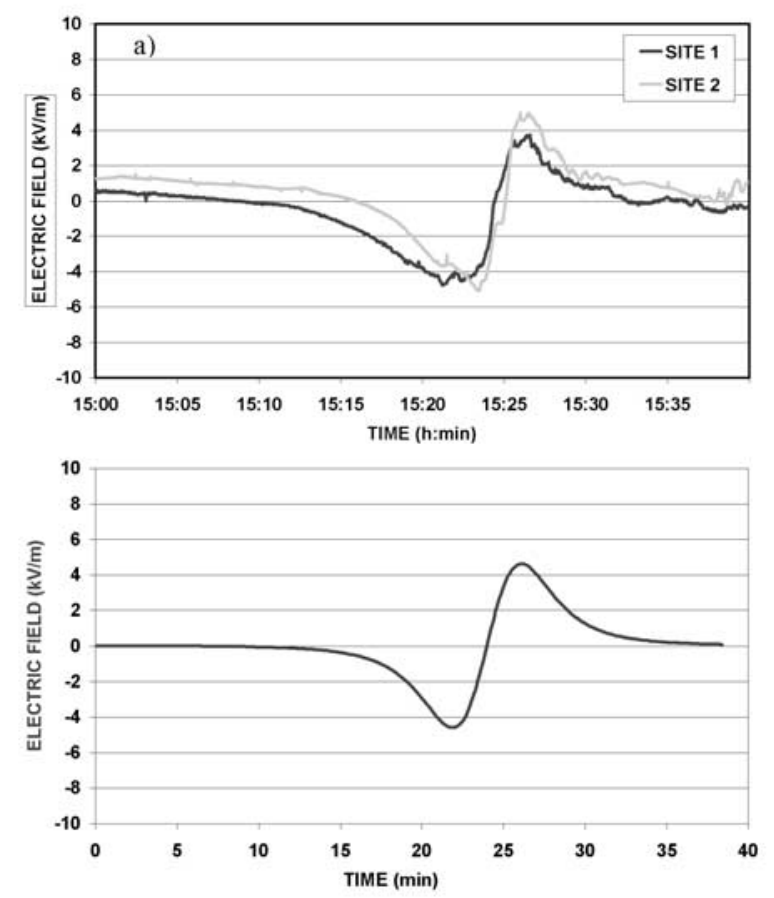

Figure 16. (a) Evolution of the electric field measured at both sites during $40 \mathrm{~min}$ between 1500 and 1540 UTC on 3 October 1999. (b) Evolution of the electric field calculated by the model during $40 \mathrm{~min}$. 
negative and positive, respectively. This reverse can be due to the different dynamics at both parts of the cell, with more vertical motion ahead. The charge given to the precipitating particles in the noninductive charge process within the cloud depends on the ambient temperature [Saunders, 1993].

[31] Without any lightning flash as it is on 3 October, the main process to eliminate the electric charge from the cloud might well be the rain transport. Therefore the scheme of the charge used in the previous model (Figure 15) is only the result of the charge transfer by the rain. Each one of the electrified thundercells observed on 3 October provided similar evolution of electric field and precipitation current at the site, but not always symmetrical for both polarities as indicated in Figure 4. These differences can be related to the stage of the cell in its lifetime.

[32] On 3 October, two kinds of convective cells could be identified from the electrical features. While the rainfall characteristics could be close in both kinds, the one produced electric field variation and a substantial precipitation current ( 6 cells, as noted before) and the other did not ( 2 cells). As seen from the main radar observations, both kinds of cells had the same vertical development. Since all cells developed within a 2-hour time interval, we can estimate that the meteorological conditions were the same. The main difference we can point out concerns the estimated vertical velocity. From these two different categories of cells, the vertical velocity appears as a key parameter for the electrification processes because the maximum of the average value calculated from RAMDAM is about four times larger when the electrical activity is present $\left(2 \mathrm{~m} \mathrm{~s}^{-1}\right.$ compared to $0.5 \mathrm{~m} \mathrm{~s}^{-1}$ ). It is known that several processes responsible for cloud electrification need a substantial vertical velocity, especially the noninductive mechanism [Takahashi, 1978; Saunders, 1993].

\section{Conclusion}

[33] Precipitation rate and electric current measurements associated with electric field detection have been made during MAP experiment that took place in a mountainous area in northern Italy. They were performed at the site of Ispra close to the Lago Maggiore at about $240 \mathrm{~m}$ of altitude. This site was close to the relief of Alps range. During the 2-month observation period in autumn 1999, several days gave rise to local electrical activity in term of electric field and precipitation current. However, little thunderstorm activity was detected at the site. Out of 5 days of measurement, only one corresponded to a real thunderstorm activity, that of 17 September. A new sensor for precipitation current detection was implemented during this campaign. A global study made from the total duration of precipitation current detection confirms the presence of both charge polarities carried by the rain. The overall proportions of both polarities are not significantly different, that of the negative one being slightly dominant. On the contrary, this proportion can be very different from a case to another. Sometimes, the event could correspond to a convective cell with a short active period and the recording made at the site was not representative of the whole cell activity. In the case of the thunderstorm activity of 17 September, the negative charge is clearly dominant.
The conclusion we can reach from the budget is that both polarities are roughly equally observed.

[34] The observation made by two Doppler radars helped to characterize the different situations. We could distinguish shallow and deeply convective cells providing different electrical activities. Two cases have been studied in detail, one with an especially strong convective cell associated with a squall line (17 September) and the other corresponding to successive shallow cells crossing above the site on 3 October. Several general remarks can be made from 7 substantially electrified convective rainfall reaching the ground: (i) the chronology of the charge carried by the rain is constant since in each convective rainfall, the charge is first negative and then positive. (ii) The electric field evolution is disturbed by the arrival of the rain at the ground (iii) The precipitation electric current often reverses when the rain rate is maximum. (iv) The polarities of the electric field and of the precipitation current density are opposite, which leads to the well-known mirror image effect.

[35] The electric field at the ground and the precipitation current were tightly correlated but the origin of the charge detected on the raindrops falling is not well established. A new interpretation of this relation has been proposed, based on observations made in several cases of shallow convective cells, on a model of charge configuration capable of restoring the field evolution and on hypothesis made by other authors about the charge extent within the cloud to interpret their observation. In this interpretation, the charge carried by the rain at the ground is opposite to that which is responsible for the surface electric field. Actually, below these cells displaying weak vertical developments, the electric field at the ground should be the result of a charge loss in the cloud by the rain. The mirror image effect could not be explained by the Wilson capture in the cases observed because the time delay theoretically necessary was not respected.

[36] On 3 October two convective cells produced substantial rainfall rates but they did not produce any electrical manifestation. The retrieved vertical velocity from radar observations showed weaker vertical motions within these cells compared to other cells of the same day with equivalent vertical development but with electrical features. This observation seems to confirm that the vertical velocity within the cloud is an important factor in the cloud electrification processes.

[37] Acknowledgments. The data used in this study have been collected during the MAP experiment at the site of ISPRA. The authors thank all participants in the MAP experiment and especially Evelyne Richard and Frank Roux from the Laboratoire d'Aérologie and Philippe Bougeault from MétéoFrance, who were strongly involved in the organization of the project. Our participation to the experiment phase was possible thanks to financial support granted by the Laboratoire d'Aérologie; we thank its director, Robert Delmas. We thank Armand Mariscal, Fabrice Gangneron and Yves Meyerfeld from the Laboratoire d'Aérologie for their technical help before and during the experiment.

\section{References}

Bougeault, P., et al., The MAP Special Observing Period, Bull. Am. Meteorol. Soc. 82, 433-462, 2001

Carey, L. D., and S. A. Rutledge, A multiparameter radar case study of the microphysical and kinematic evolution of a lightning producing storm, Meteorol. Atmos. Phys., 59, 33-64, 1996.

Carey, L. D., and S. A. Rutledge, Electrical and multiparameter radar observations of a severe hailstorm, J. Geophys. Res., 103, 13,97914,000, 1998. 
Chauzy, S., and S. Despiau, Rainfall rate and electric charge and size of raindrops of six spring showers, J. Atmos. Sci., 37, 1619-1627, 1980.

Chauzy, S., and S. Soula, General interpretation of surface electric field variations between lightning flashes, J. Geophys. Res., 92, 5676-5684, 1987.

Chong, M., et al., Real-time wind synthesis from Doppler radar observations during the Mesoscale Alpine Programme, Bull. Am. Meteorol. Soc., $81,2953-2962,2000$

Coquillat, S., O. Pace, S. Chauzy, and S. Soula, Microphysical characteristics of surface precipitation produced by convective systems during the MAP experiment, paper presented at 5th International Workshop on Physics of Lightning, Nagoya Inst. of Technol., Nagoya, Japan, 10-13 Sept. 2001

Fuquay, D. M., Positive cloud-to-ground lightning in summer thunderstorms, J. Geophys. Res., 87, 7131-7140, 1982.

Gunn, R., Electric field regeneration in thunderstorms, J. Meteorol., 11, $130-138,1954$.

Holden, D. N., C. R. Holmes, C. B. Moore, W. P. Winn, J. W. Cobb, J. E. Griswold, and D. M. Lytle, Local charge concentrations in thunderclouds, paper presented at Sixth International Conference on Atmospheric Electricity, Univ. of Manchester, Manchester, England, 1980.

Lang, T. J., S. A. Rutledge, J. E. Dye, M. Venticinque, P. Laroche, and E. Defer, Anomalously low negative cloud-to-ground lightning flash rates in intense convective storms observed during STERAO-A, Mon. Weather Rev., 128, 160-173, 2000.

MacGorman, D. R., and D. W. Burgess, Positive cloud-to-ground lightning in tornadic storms and hailstorms, Mon. Weather Rev., 122, 1671-1697, 1994.

MacGorman, D. R., and W. D. Rust, The Electrical Nature of Storms, Oxford Univ. Press, New York, 1998.

Marshall, T. C., and W. D. Rust, Electric field soundings through thunderstorms, J. Geophys. Res., 96, 22,297-22,306, 1991.

Marshall, T. C., and W. P. Winn, Measurements of charged precipitation in a New Mexico thunderstorm: Lower positive charge centers, J. Geophys. Res., 87, 7141-7157, 1982.

Marshall, T. C., W. D. Rust, and M. Stolzenburg, Electrical structure and updrafts in thunderstorms over the southern Great Plains, J. Geophys. Res., 100, 1001-1016, 1995.

Moore, C. B., and B. Vonnegut, The thundercloud, in Lightning, vol. 1, Physics of Lightning, edited by R. H. Golde, pp. 51-98, Academic, San Diego, Calif., 1977.
Orville, R. E., R. W. Henderson, and L. F. Bosart, An East Coast lightning detection network, Bull. Am. Meteorol. Soc., 64, 1029-1037, 1983.

Petersen, W. A., S. A. Rutledge, and R. E. Orville, Cloud-to-ground lightning observations from TOGA COARE: Selected results and lightning location algorithms, Mon. Weather Rev., 124, 602-620, 1996.

Ramsay, M. W., and J. A. Chalmers, Measurement on the electricity of precipitation, O. J. R. Meteorol. Soc., 86, 530-539, 1960.

Rust, W. D., and C. B. Moore, Electrical conditions near the bases of thunderclouds over New Mexico, Q. J. R. Meteorol. Soc., 100, 450-468, 1974.

Rust, W. D., D. R. MacGorman, and R. T. Arnold, Positive cloud-to-ground lightning flashes in severe storms, Geophys. Res. Lett., 8, 791-794, 1981. Saunders, C. P. R., A review of thunderstorm electrification processes, J. Appl. Meteorol., 32, 642-655, 1993.

Seimon, A., Anomalous cloud-to-ground lightning in an F5-tornado-producing supercell thunderstorm on 28 August 1990, Bull. Am. Meteorol. Soc., 74, 189-203, 1993.

Simpson, G., Atmospheric electricity during disturbed weather, Geophys. Mem. London, 84, 51, 1949.

Soula, S., and S. Chauzy, Multilevel measurement of the electric field underneath a thundercloud: 2. Dynamical evolution of a ground space charge layer, J. Geophys. Res., 96, 22,327-22,336, 1991.

Soula, S., and S. Chauzy, Charge transfer by precipitation between thundercloud and ground, J. Geophys. Res., 102, 11,061-11,069, 1997.

Standler, R. B., and W. P. Winn, Effects of coronae on electric fields beneath thunderstorms, O. J. R. Meteorol. Soc., 105, 285-302, 1979.

Tabary, P., and G. Scialom, MANDOP analysis over complex orography in the context of the MAP experiment, J. Atmos. Oceanic Technol., 18(8), $1293-1314,2001$.

Takahashi, T., Riming electrification as a charge generation mechanism in thunderstorms, J. Atmos. Sci., 35, 1536-1548, 1978.

Whipple, F. J. W., and J. A. Chalmers, On Wilson's theory of the collection of charge by falling drops, Q. J. R. Meteorol. Soc., 70, 103-119, 1944. Wilson, C. T. R., Some thundercloud problems, J. Franklin Inst., 208, $1-12,1929$.

S. Chauzy, M. Chong, S. Coquillat, J. F. Georgis, Y. Seity, and S. Soula, Laboratoire d'Aérologie, UMR 5560 UPS/CNRS, OMP, 14 avenue Edouard Belin, 31400 Toulouse, France. (sous@aero.obs-mip.fr)

P. Tabary, Météo-France, 7 rue Teisserence De Bort, B. P. 202, 78195 Trappes, France. (pierre-tabary@meteo.fr) 